IAB-DISCUSSION PAPER

25|2020 Cash-for-care, or caring for cash? The effects of a home care subsidy on maternal employment, childcare choices, and children's development

Matthias Collischon, Daniel Kuehnle, Michael Oberfichtner 


\section{Cash-for-care, or caring for cash? The effects of a home care subsidy on maternal employment, childcare choices, and children's development}

Matthias Collischon (University of Erlangen-Nuremberg)

Daniel Kuehnle (University of Duisburg-Essen and CINCH, Institute for the Study of Labor (IZA))

Michael Oberfichtner (Institut für Arbeitsmarkt- und Berufsforschung (IAB))

Mit der Reihe „IAB-Discussion Paper“ will das Forschungsinstitut der Bundesagentur für Arbeit den Dialog mit der externen Wissenschaft intensivieren. Durch die rasche Verbreitung von Forschungsergebnissen über das Internet soll noch vor Drucklegung Kritik angeregt und Qualität gesichert werden.

The "IAB-Discussion Paper" is published by the research institute of the German Federal Employment Agency in order to intensify the dialogue with the scientific community. The prompt publi-cation of the latest research results via the internet intends to stimulate criticism and to ensure research quality at an early stage before printing. 


\section{Contents}

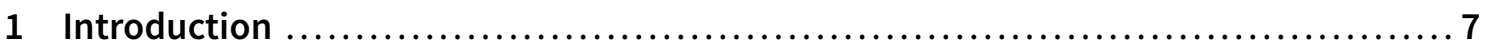

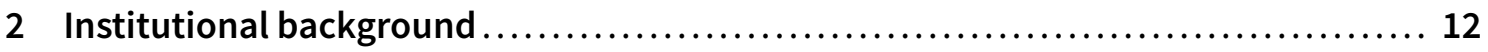

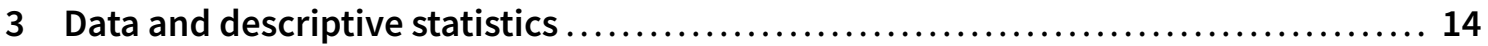

3.1 Data on employment outcomes....................................... 14

3.2 Data on take-up and childcare choices ................................ 15

3.3 Data on child development .......................................... 16

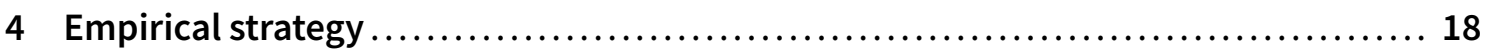

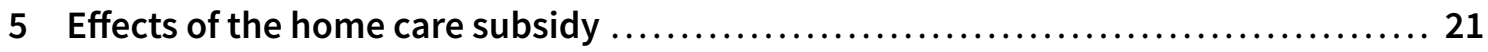

5.1 Employment effects .................................................21

5.2 Effects on childcare choices .......................................... 22

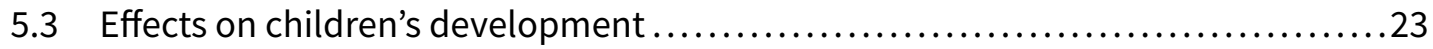

5.4 Robustness checks .................................................... 24

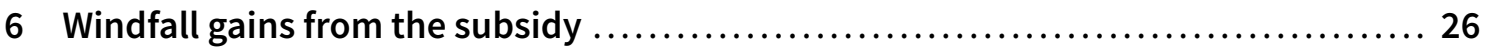

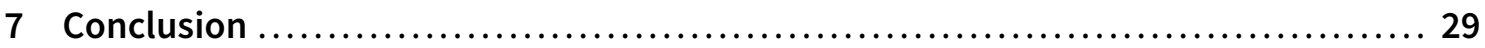

References............................................................. 31

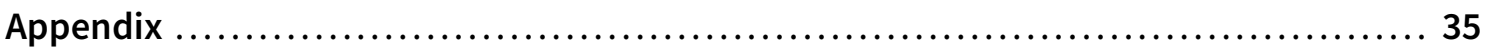

List of Figures

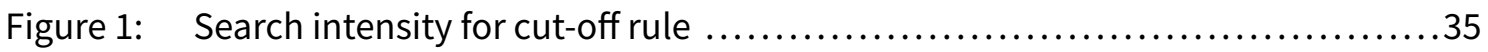

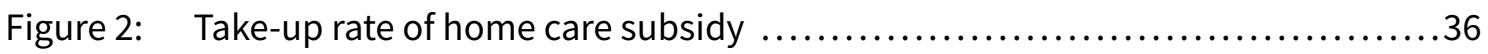

Figure 3: Common trends in employment outcomes within three years ................37

Figure 4: Reduced form relationship for children's outcomes ...................... 38

Figure A.1: Distribution of identified births in 2012 .............................. 47

Figure A.2: Take-up rate of home care subsidy in Schleswig-Holstein. $\ldots \ldots \ldots \ldots \ldots \ldots \ldots 48$

Figure A.3: Kaplan-Meier graph for return-to-work patters. .........................49 


\section{List of Tables}

Table 1: Descriptive statistics - childcare \& employment data $\ldots \ldots \ldots \ldots \ldots \ldots \ldots \ldots \ldots \ldots$

Table 2: Descriptive statistics - school entrance examinations data ..................40

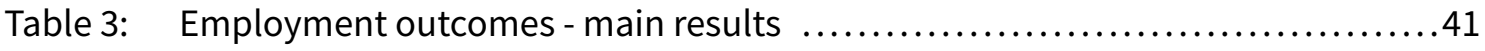

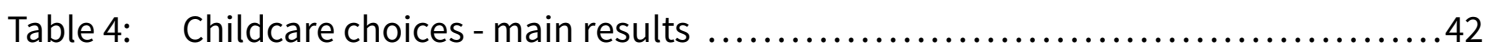

Table 5: Children's outcomes - main results .................................... 43

Table 6: Robustness checks .................................................. 44

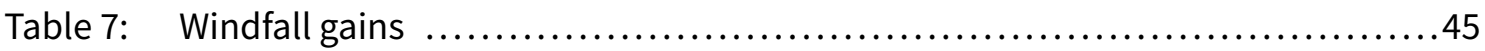

Table 8: Take-up of childcare allowance by household income prior to birth. ..........46

Table A.1: Literature review .................................................. 50

Table A.2: Key characteristics of the different datasets ........................... 52

Table A.3: Effect on social assistance receipt ...................................... 53

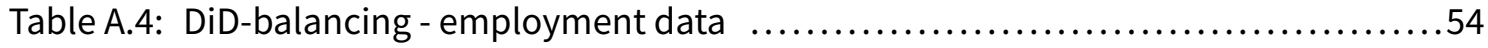

Table A.5: DiD-balancing - school entrance examinations data ....................... 55

Table A.6: Main Results for employment outcomes for Schleswig-Holstein . ..............56

Table A.7: Robustness checks for children's outcomes .............................. 57

Table A.8: Take-up of home care subsidy by parents' wage tercile prior to birth. ..........58 


\section{Abstract}

How parents respond to changes in the price of childcare is an important, though not fully understood, public policy question. Our paper provides new comprehensive evidence on how a home care subsidy jointly affects maternal labour market outcomes, childcare choices, and children's development. We examine a German reform from 2013 which introduced a home care subsidy of initially 100 Euros per month for families who do not use subsidised childcare. Exploiting a date-of-birth cut-off in eligibility and using administrative data on employment and child development alongside survey data on childcare usage, we show that the reform reduced mothers' likelihood to return to work within three years by only 1.4 percentage points, but decreased childcare enrolment for one- and two-year olds by 5 percentage points. We find no effect on children's skill development at age six. Our findings imply that the subsidy accrued almost completely as windfall gains to families who would not have used formal childcare anyway.

\section{Zusammenfassung}

Wie Familien auf Kinderbetreuungskosten reagieren, ist für viele Politikentscheidungen relevant. Diese Studie untersucht daher die Effekte des 2013 bundesweit eingeführten Betreuungsgelds für Familien mit Kindern unter drei Jahren, die keine öffentlich geförderte Kinderbetreuung besuchen, auf die Erwerbsverläufe der Mütter, den Besuch geförderter Kinderbetreuung und die Fähigkeiten der Kinder. Administrative Daten zu den Erwerbsverläufen der Mütter und zur späteren Schuleignung der Kinder kombiniert die Studie mit Befragungsdaten zum Besuch geförderter Kinderbetreuung. Die Möglichkeit, Betreuungsgeld zu beziehen, verringerte den Anteil der Mütter, die innerhalb von drei Jahren nach der Geburt in Beschäftigung zurückkehren, um 1,4 Prozentpunkte. Der Anteil der Kinder, die im Alter von einem und zwei Jahren eine geförderte Kinderbetreuung besuchen, sank um etwa fünf Prozentpunkte. Es zeigen sich keine Effekte auf die Schuleignung der Kinder. Insgesamt flossen die Ausgaben für das Betreuungsgeld größtenteils Familien zu, die auch ohne das Betreuungsgeld keine geförderte Kinderbetreuung genutzt hätten.

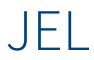

J13, J18, J22. 


\section{Keywords}

cash-for-care, childcare choices, children's development, home care subsidy, maternal labour supply, windfalls gains

\section{Acknowledgments:}

The authors would like to thank Luise Görges, Laszlo Goerke, Jonas Jessen, Guyonne Kalb, Regina T. Riphahn, Stefanie Schurer, Katharina Wrohlich, Miriam Wuest, Florian Zimmermann, and participants at the IAB \& FAU Workshop Gender economics and the workplace 2018, the DIW research seminar, the University of Trier research seminar, the 2019 VfS conference in Leipzig and the $8 \mid$ KSWD conference in Berlin as well as various internal seminars for their helpful comments and suggestions. 


\section{Introduction}

Over the last four decades, maternal employment rates have increased substantially across all OECD countries. Mirroring this trend, access to universal childcare programmes for children below age three has also expanded and current initiatives push to increase access further (e.g., see OECD, 2017). In most countries with universal programmes, families using these programmes pay only a fraction of the costs and subsidies cover the remainder (OECD, 2016). These substantial subsidies gave rise to discussions whether families not using subsidised childcare should also receive public support in the form of home care subsidies, also known as cash-for-care programmes. Such home care subsidies were for instance implemented in Finland, Norway, Sweden, and in Germany at the national level and - in different forms - in the states of Thuringia and Bavaria. In each case, the home care subsidies caused heated debates. Proponents argued that they give families the freedom to choose the optimal childcare arrangement for them, whereas opponents raised concerns that such subsidies reduce maternal employment and hinder children's skill development by reducing enrolment in subsidised childcare (Duvander/Ellingsæter, 2016).

Labour supply models predict that the subsidy will reduce maternal employment by increasing the costs of childcare. ${ }^{1}$ Studies for Norway (Naz, 2004; Drange, 2015; Schøne, 2004; Thoresen/Vattø, 2019), Sweden (Giuliani/Duvander, 2017), Finland (Kosonen, 2014) and Thuringia (Gathmann/Sass, 2018) confirm these negative effects on maternal employment, although the effects are typically small.

Regarding children's skill development, the theoretical prediction is ambiguous as home care subsidies may affect children's skill development through two different channels. First, home care subsidies likely reduce the use of formal childcare (as Thoresen/Vattø (2019) find for Norway and Gathmann/Sass (2018) find for Thuringia) and hence children eligible for the subsidy will spend more time in other care modes. Depending on the difference in the quality of childcare provided in the different care environments, this change in childcare modes may either improve or impair children's development (see, e.g., Cascio, 2015; Cornelissen et al., 2018; Fort/Ichino/Zanella, 2020). Second, home care subsidies affect household income, which determines the resources parents can invest in their children (e.g. Løken/Mogstad/Wiswall, 2012), and several studies show that changes in parental resources early in a child's life may affect children's development in the short- to long-run (e.g. Currie/Almond, 2011). However, Heckman/Mosso (2014) and Carneiro/Ginja (2016) conclude that children's skill development

1 Home care subsidies in Norway, Sweden and Thuringia are gradually withdrawn as families use more subsidised childcare, and thus the subsidies increase the hourly costs of childcare. Finland, Germany at the national level, and Bavaria paid lump-sum subsidies that were withdrawn completely if families use any subsidised childcare, and the subsidies thus acts as an entrance fee. Both types enlarge families' choice set, and in particular raise their consumption opportunities if they do not use subsidised care (and do not participate in the labour market). Hence, a static model of labour supply predicts that both types of home care subsidies reduce labour supply. 
does typically not benefit from temporary and unrestricted transfers, such as the home care subsidy. The empirical evidence on the effects of home care subsidies on children's skill development is based on survey data from Thuringia, where Gathmann/Sass (2018) find some evidence for positive effects of the home care subsidy on children's development for two-year olds.

This paper contributes comprehensive evidence on the effects of the introduction of a home care subsidy in Germany in 2013 on maternal employment, childcare choices and child development. Parents with children under age three became eligible for the subsidy once both parents could no longer claim paid parental leave benefits and if they did not use any form of subsidised childcare. Parents could receive the subsidy for up to 22 months, typically from month 15 through at most month 36 , which is also the last month of unpaid parental leave. The subsidy initially amounted to 100 Euros per month, which corresponds to roughly 50 percent of average parental fees for subsidised care, and it was increased to 150 Euros in August 2014. Our identification strategy exploits the institutional rule that only parents of children born from 1 August 2012 onwards were eligible for the subsidy. Although this cut-off date generates exogenous variation in eligibility for the subsidy, we cannot use a regression discontinuity design as the start of the childcare year (in autumn) gives rise to seasonal variation in mothers' labour supply. To correct for these seasonal differences, our baseline estimation uses a difference-in-differences (DiD) strategy that adjusts for the difference in outcomes between children born in the same calendar months, but in years not affected by eligibility for the subsidy.

We make three major contributions to the literature. First, using administrative social security records on employment alongside detailed household survey data on take-up of the subsidy and on childcare choices, we examine how the introduction of a home care subsidy in Germany affected maternal employment and childcare arrangements. Despite substantial take-up of the subsidy (around 60\%), we document that within three years after child birth the subsidy reduced maternal employment only minimally (-1.4 percentage points, baseline $82.8 \%$ ) and led to a substitution away from using subsided childcare (-5 pp, baseline $49.4 \%)$. This finding is consistent with previous studies from the Nordic countries which show that home care subsidies have only small effects on employment even when take-up of the subsidy is high, but can alter childcare choices.

Second, we examine how care subsidies affect children's skill development using administrative data. Our data relies on compulsory school entrance examinations at age six and cover the full population of children from one federal state. We examine a variety of cognitive and non-cognitive skill dimensions, including cognition, attention, hand-eye coordination, counting and numeracy, that are assessed by public health paediatricians. We find no evidence that the home care subsidy substantially impacted children's skills development at age six. 
Third, the wide gap between take-up and employment effects indicates that many recipients of the subsidy did not change their behaviour regarding employment and childcare choices and that the home care subsidy thus created substantial windfall gains. ${ }^{2}$ As the previous studies on home care subsidies have not analysed the extent and beneficiaries of such windfall gains, our third contribution addresses this issue by bringing together the effects of the home care subsidy on maternal employment and childcare choices with the take-up of the subsidy. Apart from distributional concerns on who receives windfall gains, the financing of these windfall gains can cause economic inefficiencies (see, e.g., Kleven/Kreiner, 2006). We provide new evidence for substantial windfall gains as the share of subsidy recipients is ten times as large as the share of those adjusting their behaviour (or even larger depending on the outcome). This finding implies that at least nine out of ten recipients did not adjust their behaviour. From a policy perspective, one can consider family's windfall gains from the home care subsidy either as an income transfer or as deadweight loss. The interpretation as an income transfer is arguably more desirable if families with the least economic resources benefited most. However, this is not what the policy achieved. We show that the subsidy transferred income particularly towards families with medium earnings potential and benefited single mothers less than couples. In terms of deadweight loss, our calculations imply that the subsidy imposed large fiscal costs that were not offset by potential savings in public expenditures for formal childcare.

Our paper adds to the literature on the effects of home care subsidies. This literature focuses on the effects on maternal employment and child care utilisation and is dominated by studies from the Nordic countries (Naz, 2004; Schøne, 2004; Drange, 2015; Thoresen/Vattø, 2019; Giuliani/Duvander, 2017; Kosonen, 2014). Overall, these quasi-experimental evaluations show that home care subsidies have limited effects on maternal employment and on childcare choices, despite substantial take-up. ${ }^{3}$ This pattern holds equally for subsidies that are gradually withdrawn as families use subsidised childcare and for subsidies that are conditional on not using subsidised care at all.

Gathmann/Sass (2018) provide the most comprehensive evaluation of a home care subsidy. They study the effects of the home care subsidy in Thuringia, a federal state in East Germany that introduced a home care subsidy prior to the national subsidy. The Thuringian subsidy was offered to parents of two-year old children, irrespective of parents' employment status.

2 Windfall gains, defined as individuals receiving a subsidy without changing their behaviour, are sometimes also referred to as deadweight effects or losses. Such windfall gains have been scrutinised in different areas of economic research, ranging from evaluations of active labour market policies (e.g. Boockmann et al., 2012), wind electricity subsidies (Haan/Simmler, 2018), subsidies for electric vehicles (Xing/Leard/Li, 2019), to the optimal design of environmental subsidy programmes (Arguedas/van Soest, 2009). Even though windfall gains of home and childcare subsidies and their potential distributional effects have been noted earlier (e.g. Duncan/ Giles 1996 and Spiess/Kreyenfeld/Wagner 2003), these studies have not used exogenous variation in eligibility for such subsidies.

3 For further details on these studies, see Appendix Table A.1. One additional study by Bettinger/Hægeland/ Rege (2014) also documents that the Norwegian home care subsidy positively affected the GPA of older siblings of eligible children in tenth grade. 
Unlike other home care subsidies, the subsidy increases with children's birth order from 150 Euros for first-born children to 300 Euros for fourth- or higher-order children. Using survey data from the German Microcensus and a difference-in-differences (DiD) estimation, the paper finds that the subsidy decreased the use of formal childcare (-8pp) and informal childcare $(-18 p p)$, while at the same time increasing exclusive home care (+18pp). Maternal employment rates decrease in the first two years after eligibility $(-4 p p)$, whereas their husband's employment probability (+7.9pp), and weekly hours worked (+1.8) increase. To assess children's development, the study uses data from the German Socio-Economic Panel (SOEP) which contains parent-reported information on children's development for children aged two to three. They find that the reform improved children's social skills as well as skills regarding daily activities.

Our study differs in three important aspects from Gathmann/Sass (2018). First, we investigate the effects of a different type of home care subsidy that alters families' budget constraints differently. The home care subsidy we study is paid out monthly only to families not using public childcare at all, whereas Thuringia's childcare subsidy was gradually withdrawn when families used some hours of subsidised childcare. Second, we use large administrative datasets on employment outcomes and on child development, whereas Gathmann/Sass (2018) base their analysis on survey data. In addition to providing much larger samples, administrative data have the additional advantage of providing outcome measures that are not self-reported. This may be particularly important with respect to child development. Whereas Gathmann/Sass (2018) use parent-reported measures of children's development, our analysis focuses on pre-schoolers that were assessed by external paediatricians. Moreover, their study is based on a small sample size ( $\mathrm{N}=434)$ spread out over several preand post-treatment birth cohorts (2003 to 2010). Third, the setting in Thuringia created differences in eligibility to the home care subsidy also for future births. Our identifying variation, in contrast, creates differences in the eligibility for the subsidy for one specific child, but does does not affect eligibility for future births.

Our paper also adds to two related strands of literature. First, we connect to a large literature on the relationship between child care prices and female labour supply (e.g., Blau/ Currie, 2006; Black et al., 2014). A large quasi-experimental literature examines how universal child care programs affect maternal employment (e.g., see Baker/Gruber/Milligan, 2019; Carta/Rizzica, 2018). Overall, this literature arrives at no conclusive generalisations. Second, we also add to the literature on determinants of children's skill development, in particular with respect to maternal employment (e.g., see Bono et al., 2016; Hsin/Felfe, 2014) and different types of child care arrangements (e.g., see Drange/Havnes, 2018; Fort/Ichino/Zanella, 2020).

The paper proceeds as follows. Section 2 gives the institutional details and Section 3 describes the three different datasets. Section 4 discusses the empirical strategy and is followed 
by Section 5 which presents the results and several robustness checks. Section 6 discusses the windfall gains from the subsidy, and Section 7 concludes the paper. 


\section{Institutional background}

This section describes the institutional setting that families face in Germany and in which the home care subsidy was introduced in 2013. Pregnant women are entitled to paid maternity leave for fourteen weeks - six weeks prior to the expected date of delivery and eight weeks after giving birth. During maternity leave, women receive their full wages. Parents can take up to 36 months of parental leave from their employers and have the right to return to their pre-birth employer afterwards. In particular, they are entitled to return to their previous (or an equivalent) job, i.e. mothers were entitled to earn the same hourly wage and work the same number of hours as before the birth. Parents are also jointly entitled to fourteen months of paid parental leave benefits (Elterngeld), a tax-financed payment that typically replaces 66 per cent of the parents' pre-birth wages, where one parent (typically the mother) can take at most twelve months.

From the mid-2000s onwards, Germany increased the supply of subsidised childcare for children below age three, and the enrolment rate of children below age three soared from 13.6 per cent in 2006 to 32.7 per cent in 2016 (BMFSFJ, 2016). Ultimately, Germany introduced a legal entitlement to a slot in subsidised childcare for all children from age one onwards in August 2013. ${ }^{4}$ At the same time, Germany introduced a home care subsidy paid to parents with children under the age of three who do not use subsidised childcare. This subsidy was only available for children born from August 2012 onwards. We focus on this home care subsidy, which around 60 percent of the eligible families in our sample received at some point. ${ }^{5}$

Parents were only entitled to the home care subsidy if they did not send their child to subsidised childcare (including both childcare centres and nannies, Tagesmuetter). The subsidy initially amounted to 100 Euros per month and was raised to 150 Euros per month in August 2014. For comparison, the median net income of working mothers with children born in 2012 aged one and two who are not eligible for the home care subsidy amounted to 1200 Euros (based on the KiBS data, see Section 3). Thus, the home care subsidy replaces roughly 10 percent of what mothers would have typically earned in the labour market, which is comparable to similar subsidies in Nordic countries (Eydal/Rostgaard, 2011). Furthermore, the average actual monthly childcare costs were roughly 200 Euros for children under three living in West Germany (own calculation based on the SOEP, 2011 and 2013), and the monthly fees for a fullday slot in major cities ranged from 200 Euros (in Frankfurt) to 540 Euros (in Gelsenkirchen, FAZ, 2012). The subsidy hence imposed a substantial fixed costs on using subsidised childcare. The home care subsidy was fully accounted as income for means-tested benefits (ALG

\footnotetext{
4 Since August 1996, children from age three until school entry have been legally entitled to a slot in subsidised childcare. Enrolment rates for children aged 3-5 in formal childcare amounted to 95\% in 2016 (OECD, 2017). Also note that no noteworthy private childcare market ever emerged in Germany, mainly because of strict regulations, high market entry, barriers, and dominance by publicly funded providers (Kreyenfeld/Hank, 2000). 5 Although the introduction of the home care subsidy and of the entitlement to a childcare slot coincide, the eligibility criteria differ which allows us to disentangle the effects, see Section 4 for details.
} 
II) and thus unavailable for families receiving other social benefits, but was neither subject to income taxation nor did it affect the marginal tax rate.

Parents could receive the subsidy for a maximum of 22 months, starting after the end of paid parental leave entitlements when children are typically 12 to 14 months old and ending at the latest at a child's third birthday. In July 2015, the German constitutional court abolished the home care subsidy on the grounds of interference with the autonomy of federal states concerning family policy. ${ }^{6}$

6 As previously approved claims were not revoked, the subsidy was not abolished at a specific date or from some birth date onwards, but it rather faded out. We thus cannot apply the same research design to estimate and compare the effects of the subsidy's abolition. 


\section{Data and descriptive statistics}

We use three different datasets to investigate the effects of the home care subsidy on maternal employment, childcare choices and child development. In particular, we employ administrative social security records on employment, a representative childcare survey for childcare arrangements, and administrative data from mandatory school entrance examinations from Schleswig-Holstein, a federal state in West Germany. ${ }^{7}$ As the state of BadenWuerttemberg augmented its supplementary state level parental benefit for low-income parents (Landeserziehungsgeld) shortly before the introduction of the national home care subsidy, we exclude all observations from this state. We focus on West Germany in our analysis due to data limitations for East Germany. ${ }^{8}$

\subsection{Data on employment outcomes}

For employment outcomes, we use the Integrated Employment Biographies (IEB V13.00.00 in combination with BEH V10.02.01) provided by the Institute for Employment Research (IAB). The data contain daily information on workers' employment, education ${ }^{9}$ and daily wages until 31 December 2016. ${ }^{10}$ The data include all workers covered by the social security system, but do not include civil servants and the self-employed, thereby covering about 80 percent of all people employed in Germany. For a detailed data description, see Jacobebbinghaus/ Seth (2007). As the employer-reported gross wages and employment durations are used to calculate contributions to and benefits from the social security system, they are extremely reliable.

We examine the following employment outcomes three years after child birth, i.e., when eligibility for the home care subsidy and unpaid parental leave expired: 1) the probability of having returned to work, 2) cumulated days in employment since child birth, and 3) cumulated labour income since child birth, i.e., the sum of her daily wages. Unfortunately, the data

\footnotetext{
7 Appendix Table A.2 provides a concise overview of the different datasets.

8 Two data problems arise for East Germany. Most importantly, we lack administrative data on children's skill development; second, we have insufficient statistical power for the analysis of childcare choices. We cannot solve the power issue by pooling West and East Germany as these two regions differ substantially with respect to maternal employment, childcare usage, and gender norms (Schnabel, 2016). For completeness, we still report and discuss the results for East Germany in Online Appendix B.

9 We use the procedure by Thomsen/Ludsteck/Schmucker (2018) to impute missing information on education. We still have around $4 \%$ of missing values in our data after the imputation and account for this using a dummy in the estimation.

10 The information on wages is censored at the social contributions ceiling. However, $98.7 \%$ of mothers in our sample have pre-birth wages below this threshold. For observations with wages above this ceiling, we recode their wages to the threshold value in the respective year. To check whether the top-coding affects our results, a robustness check excludes all women whose wage was above social contributions ceiling at any time during our analysis period. Excluding these mothers does not alter our results, see Section 5.4.
} 
does not include information on hours worked; we therefore examine cumulated outcomes to additionally capture changes at the intensive margin.

One shortcoming of the the social security records is that they do not provide direct information on children. To overcome this issue, we use the procedure by Müller/Strauch (2017) to identify births and the expected date of delivery. ${ }^{11}$ Employers need to notify social insurances about the start date of the maternity leave period, i.e. six weeks before the expected date of delivery. As the same notification code is also used in some cases of longer illnesses, the method by Müller/Strauch (2017) employs several checks to ensure that the notification reflects a child birth and, if so, identifies the expected date of birth as six weeks after the beginning of maternity leave. Thus, the method identifies the expected date of delivery, which may differ slightly from the actual date of childbirth. To avoid misassigning mothers between the treatment and the control group, we exclude births with an expected date of delivery in a window of two weeks around the eligibility cut-off date (1 August 2012). Higher-order births are typically unobservable when the mother does not return to work between consecutive births, for instance because of a low labour market attachment. To avoid the sample selection stemming from such a pattern, our analyses of the effects on maternal employment outcomes focuses on first-time mothers.

Our employment data include all women whom we identify as giving birth for the first time between 2008 and 2013 and who worked subject to social insurance directly before giving birth. We exclude mothers in Baden-Wuerttemberg based on place of residence during the last employment spell before giving birth. We furthermore exclude mothers who receive social assistance (ALG II) two years prior or within three years after giving birth as the home care subsidy affected these mothers differently. ${ }^{12}$ Overall, our estimation samples consists of around 500,000 births. Panel A of Table 1 provides the descriptive statistics for mothers of children born in 2012.

\subsection{Data on take-up and childcare choices}

To examine the effect on childcare choices, we use the KiBS (Kinderbetreuungsstudie) childcare panel survey which has been conducted annually by the German Youth Institute (DJI) since 2012. Between 2012 and 2016, the study surveyed the parents of around 13,000 children under age three each year. The survey follows a two-stage sampling scheme. It first randomly samples municipalities by federal state and municipality size and then samples children from these municipality. To account for this sampling scheme, we use the provided

\footnotetext{
11 Using the same data source to examine the effect of changes in parental leave regulations on mothers' careers, Schönberg/Ludsteck (2014) applied a similar method.

12 We also checked whether the reform affected the probability of receiving social assistance at any time within 36 months after child birth. The results presented in Appendix Table A.3 show that the reform did not affect takeup of social assistance.
} 
sample weights throughout our analysis. The survey asks parents about the childcare arrangements of the sampled child and provides detailed information on socio-demographic characteristics of the parents and the household. Importantly, the study includes children's year and month of birth, which determine eligibility for the home care subsidy. Even though the KiBS is a panel study, the questionnaires differ between waves, which prevents us from including some variables in our DiD estimations. For a detailed description of the survey, see Alt et al. (2018). Again, we exclude observations from Baden-Wuerttemberg based on the place of residence at the time of the survey. Our final estimation sample consists of 9,104 observations. Panel B of Table 1 provides descriptive statistics for mothers of children born in 2012.

\subsection{Data on child development}

We supplement our main analysis with administrative data from school entrance examinations that cover the full population of one West German federal state, Schleswig-Holstein. ${ }^{13}$ These examinations are mandatory in Schleswig-Holstein and are carried out before children enter primary school at age six. During the medical examination, a public health paediatrician examines children's development in numerous dimensions. ${ }^{14}$

Our data contains information for all school entrance cohorts between 2014 and 2019. A school entrance cohort includes children born between July of the previous year and June of the year of school entrance. We therefore have information for all children who where born between July 2007 and June 2013. Unfortunately, we cannot use all these children for our empirical analysis as the introduction of the home care subsidy for children born from August 2012 onwards coincides almost perfectly with the beginning of a new school entrance cohort. To be able to cleanly isolate the effect of the home care subsidy from any fixed differences between examination cohorts, we only examine children born in July or August of a given calendar year as they are part of the same school entrance cohort. We still end up with a sample size of around 10,000 children.

The data includes detailed information about children's cognitive and non-cognitive development that are used as a screening tool developed specifically for school entry examinations (Sozialpädiatrisches Entwicklungsscreening für Schuleingangsuntersuchungen, SOPESS;

\footnotetext{
13 Schleswig-Holstein covers 3.6\% of the German population. Kuehnle/Oberfichtner (2020) use data from the German Microcensus to show that the demographic and socio-economic characteristics of the population of Schleswig-Holstein are almost indistinguishable from the population of other West-German states, with the exception of urbanity and migration background. To further alleviate concerns about comparability, we calculate take up rates in the KiBS data and find similar rates for Schleswig-Holstein (57\%) and West Germany (62\%); Appendix Figure A.2 provides information on take up by birth month. Finally, Appendix Table A.6 documents that we find similar employment results for Schleswig-Holstein as for entire West Germany.

14 This data source has been used used in other contexts, see Felfe/Zierow (2018), Felfe/Lalive (2018), Felfe/ Rainer/Saurer (2019), Huebener/Kuehnle/Spiess (2019) and Kuehnle/Oberfichtner (2020).
} 
Oldenhage/Daseking/Petermann 2009). The tool is used to help identify i) difficulties in basic school-relevant skills and ii) children's need for further therapy or treatments. We focus on the following five outcomes that are collected in a standardised way during the screening: cognition, selective attention, hand-eye coordination, counting, and numeracy. These outcomes have been shown to correlate strongly with physicians school readiness recommendations in other contexts (Daseking/Petermann/Simon, 2011). We turn the standardised outcome variables for children's outcome in these development domains into binary variables that indicate developmental difficulties. ${ }^{15}$ As a robustness check, we also examine outcomes that have been collected in a non-standardised way (speech difficulties, motor skills, and a doctor's recommendation whether children need additional support to be able to participate in school); we reach the same findings with these outcomes.

In addition, the data contains information on children's year and month of birth and some information about family characteristics, such as parental schooling, migration background, and main language spoken at home. This information is reported voluntarily by the accompanying parent (typically the mother). The data does not contain information about parental income. Table 2 provides descriptive statistics for mothers of children born in July and August of 2012.

15 For more details on these outcomes, see Online Appendix C. 


\section{Empirical strategy}

An intuitive approach to estimate the effect of the home care subsidy would be a regresssion discontinuity design (RDD) that exploits the eligibility cut-off. However, an RDD approach is not feasible in our context as the childcare year in Germany starts in August or September, depending on the federal state, giving rise to seasonal variation in mothers' labour supply three years after giving birth. To correct for these seasonal differences, our baseline estimation uses a DiD strategy that adjusts for the difference in outcomes between children born in the same calendar months, but in years not affected by eligibility for the subsidy. Specifically, we distinguish between mothers giving birth between March and July (control group) and those giving birth between August and December (treated group) of the same calendar year. The identifying comparison then comes down to asking whether any differences between these two groups differ between children born in 2012 and those born in other years.

Identifying the causal effects of the home care subsidy from the discontinuity in eligibility requires that parents did not time their births systematically around the eligibility cut-off to become eligible for the home care subsidy. In our context, strategic birth timing is not an issue for two reasons. First, the original draft proposal from June 2012 (Bundestag 17/9917) made anticipatory changes impossible as the draft listed 1 January 2012 as the eligibility cut-off date. Second, without receiving any public attention (FAZ, 2013), the eventual cut-off date (1 August 2012) was introduced between the draft and the final law (November 2012, Bundestag 17/11404). This unexpected and publicly unnoticed change practically ruled out any strategic timing of births around the cut-off and many parents with children born before August 2012 were surprised that they were not eligible for the subsidy once it was introduced. Google Trends data on searches regarding a cut-off date for the home care subsidy confirm this surprise: Figure 1 documents hardly any searches for a cut-off date until late 2012. Rather, searches for the eligibility cut-off spiked in August 2013 - when many individuals eventually realised they were (not) eligible for the subsidy.

To estimate the effect of the home care subsidy on different outcomes, we specify the following baseline DiD model:

$y_{i}=$ byear $_{i}+\beta_{1} \times \mathbf{1}\left[\right.$ autumn $\left._{i}\right]+\delta \times \mathbf{1}\left[\right.$ autumn $\left._{i}\right] \times \mathbf{1}\left[\right.$ byear $\left._{i}=2012\right]+\epsilon_{i}$

where we regress the outcomes $y_{i}$ (of mothers or children) on a vector of indicator variables for children's year of birth $\left(\right.$ byear $\left._{i}\right)$, and autumn $_{i}$ indicates whether a child was born between August and December. Thus, $\delta$ yields the average effect of being entitled to the subsidy. $\epsilon_{i}$ is an error term. For our baseline specification, we include births born within five months of the eligibility cut-off, i.e., between March and December. ${ }^{16}$ To increase precision and to check

16 As discussed in Section 3, we can only include children born in July and August using the school entrance examinations data. 
the robustness of our estimations, we add observable characteristics and region effects in further regressions. As additional robustness checks, we employ (where possible) differencein-discontinuities (DiDisc) estimations, include group-specific time trends, and reduce the size of the observation window to decrease any potential biases arising from births further away from the cut-off.

To provide unbiased estimates for the causal effect of the home care subsidy, our identification strategy requires three main assumptions. The first assumption requires common trends in potential outcomes between the treated and control groups. The reduced form graphs (see Figures 3 and 4) and placebo tests that we discuss in Section 5 strongly support the common trends assumption. ${ }^{17}$

Second, our identification strategy requires an exogenous treatment and that the composition of the groups does not change differentially over time. To investigate the exogeneity of the treatment, we examine the (standardised) differences in explanatory variables measured prior to child birth between treated and control group children. Tables 1 and 2 present the descriptive statistics, separately by season of birth. To check the identification assumption, we perform covariate balancing tests within the DiD framework and replace the dependent variable in equation 4.1 with each of these explanatory variables. The results presented in Appendix Tables A.4 and A.5 support the absence of compositional changes. We also observe no shifts in the distribution of births (see Appendix Figure A.1).

Third, our strategy requires that no other policy changes differently affected childcare choices or employment outcomes for the treatment and the control group. We are not aware of any such policies. Although we noted in Section 2 that the introduction of the home care subsidy coincides with the introduction of the entitlement to a childcare slot, we can cleanly disentangle the effect of the home care subsidy as the eligibility criteria differ: Only parents of children born from 1 August 2012 onwards became entitled to the home care subsidy. The entitlement to a childcare slot, in contrast, was introduced for all children on 1 August 2013 irrespective of their date of birth. Thus, parents of children born in July 2012 differ from parents of children born in August 2012 discontinuously in their eligibility to the home care subsidy. In contrast, the difference in the age at which children became entitled to a childcare slot does not change discontinuously by date of birth. We can hence exploit the discontinuity in eligibility to the home care subsidy by birth month to explore the subsidy's effects on maternal employment outcomes, childcare choices, and children's development. ${ }^{18}$

\footnotetext{
17 As the KiBS data contain information on childcare choices only for children born in 2011 and 2012, i.e. one pre-treament period, we cannot investigate the pre-treatment trends for these outcomes.

18 We conduct a placebo test that alleviates concerns that the described differences in eligibility might confound our results. Specifically, we use births in autumn 2011 as placebo treatment group and births in spring 2011 as placebo control groups. In a similar pattern to the actual treatment and control groups, both of these placebo groups became legally entitled to a slot in public childcare on 1 August 2013, which was after the children's second birthday for children born in spring 2011 and before that birthday for children born in autumn. As
} 
none of these children were eligible for the home care subsidy, comparing these groups isolates differences that stem from becoming entitled before or after a birthday. As Section 5.4 shows, we find no differences between these two groups. 


\section{Effects of the home care subsidy}

As a starting point for our analysis, Figure 2 depicts the take-up of the home care subsidy by children's month of birth for children born between March 2012 and December 2012. The figure clearly shows that take-up jumps up by around 60 percentage points between July and August. Although families with children born until July 2012 were not eligible for the subsidy, a few of these families reported that they received the subsidy. These answers most likely reflect reporting errors as administrative errors are highly unlikely. From August onwards, the share of families receiving the subsidy remains fairly constant.

\subsection{Employment effects}

We begin with a visual inspection of the reduced form in Figure 3 which depicts the employment outcomes separately for mothers of children born in spring and autumn from 2008 through 2013. Supporting the common trends assumption, the employment outcomes of both groups develop in parallel across the different birth cohorts until 2011. Before the introduction of the home care subsidy, women who gave birth in autumn have slightly better employment outcomes three years post birth than mothers who gave birth in spring. When the subsidy is introduced, this pattern reverses: Mothers newly eligible for the subsidy (with children born in autumn of 2012) exhibit a lower likelihood to return to work within three years, were employed fewer days, and had slightly lower earnings compared to mothers who gave birth in spring of 2012. All mothers' who gave birth in 2013 were eligible for the home care subsidy, and the difference between mothers giving birth in spring and autumn reverses to the pattern observed between 2008 and 2011.

Table 3 presents the regression results for the three employment outcomes. The first row reports our baseline DiD estimates according to equation 4.1 with controls for maternal characteristics (education, age at birth, and pre-birth wages) and district fixed effects. Being eligible for the subsidy reduced the probability to have ever worked within 36 months after child birth by 1.4 percentage points $(-1.7 \%)$. The smaller probability to return to work translates into lower work experience and cumulated earnings in these 36 months: The reform reduced the cumulated time in employment by 13.5 days $(-3 \%)$ and the cumulated labour income by 907 Euros (-3.2\%). Overall, employment does not respond strongly to the increased childcare costs. ${ }^{19}$

19 Exploiting the information on employment at the daily level, Appendix Figure A.3 plots the Kaplan-Meier return-to-work patterns for the first three years after child birth separately for spring and autumn births from 2011 and 2012. The figure shows that return-to-work patterns are similar between the four groups during the first year after childbirth, and that they start to diverge between autumn and spring births when children are aged 13-24 months. 
Panels $B$ and $C$ of Table 3 present the results by educational attainment and citizenship. Panel $B$ shows that the effects on the probability to return to work and on cumulated days in employment are smaller for mothers with a tertiary degree than for mothers without tertiary degree. Due to the higher earnings of mothers with a tertiary degrees, the employment effects translate into a loss of cumulated labour income of similar relative size in both groups. Splitting the sample by citizenship yields no difference in the effect sizes, though the effect remains statistically insignificant for non-native mothers due to the smaller sample size. Whereas critics worried that the employment disincentives set by the home care subsidy would have larger negative employment effects on non-natives or low-educated mothers, our analysis does not reveal substantial differences in the employment effect by education or citizenship. Differences between the groups are statistically insignificant in all cases (see notes for Table 3).

\subsection{Effects on childcare choices}

Despite the small effects on maternal employment outcomes, the home care subsidy could still have affected childcare choices. For instance, parents could try to coordinate their schedules to avoid subsidised childcare and instead provide care themselves. Table 4 hence presents the estimated treatment effect for the use of subsidised childcare. ${ }^{20}$

Our baseline DiD models control for maternal age at birth and education (whether mothers hold a tertiary degree), state fixed effects, survey year fixed effects and children's age in months (as dummies) to control for the different timing of the survey. ${ }^{21}$ Panel A shows that the home care subsidy on average reduced the probability to attend subsidised childcare by 5.3 percentage points, which is statistically significant at the 10 percent level. This reduction in subsidised childcare attendance (prior to age three) is four times as large as the effect on returning to work within three years. ${ }^{22}$

Next, we again split the sample by educational attainment and two definitions of migration background. These results yield a more nuanced picture of the effect of the home care subsidy on attending subsidised childcare for different subgroups. The estimated effects on childcare attendance by maternal education (Panel B) are of similar magnitude, though the effect is statistically insignificant for mothers with a tertiary degree-arguably due to lower precision in this sample. Next, we investigate the reform's effects by migration background splitting the

\footnotetext{
20 Unfortunately, the survey does not consistently measure exclusive parental care and we therefore cannot include this care mode as an outcome.

21 Even though the survey contains information on the partner's education, we cannot use it as a control variable because it is not collected consistently across survey waves. As a robustness check, we also added partner's education as a control variable (including a dummy for missing values). This hardly affects our main results, the coefficient in this specification is -0.050 with a standard error of 0.028 .

22 In line with this estimate, the KiBS data show that $5 \%$ of parents who did not use subsidised childcare at the time of the survey stated that they would use subsidised childcare if there was no home care subsidy.
} 
sample by the main language spoken at home in panel $\mathrm{C}$ and by parental country of origin in panel D. We find a somewhat larger reduction in the use of subsidised care in households in which German is not the main language than in other households. The difference by parental country of origin is less pronounced, but points in the same direction. Although the differences between natives and migrants are not statistically significant with both measures for migration background, our results suggest that the home care subsidy reduced subsidised childcare attendance more strongly for children with a migration background. ${ }^{23}$

\subsection{Effects on children's development}

Finally, we address the question whether the subsidy affected children's development. Figure 4 presents the reduced form relationship and shows children's outcomes by year of birth separately for children born in July and August. The figure provides strong evidence for the common trends assumption, as the outcomes of both groups of children develop in parallel across the different birth cohorts until 2011. Moreover, the figure also indicates that the home care subsidy did not have a strong impact on the considered outcomes.

Table 5 presents the corresponding regression results. The coefficients presented in the first column confirm the visual evidence and document that the reform did not affect the examined outcomes on average. Columns two and three split the sample by mothers' highest educational level and generally show that the reform did not affect either of the two groups in a significant way. Moreover, the point estimates for children of mothers with low education are negative, indicating improvements, though the estimates lack precision. Similarly, when we split the sample by mothers' migration background, following the same definitions as in the childcare data, we again observe no economically meaningful or statistically significant effects (apart from one counting difficulties for children where the main language spoken at home is German, though this appears to be statistical noise).

Overall, we document that the home care subsidy did not affect children's development on average, and also suggests that more disadvantaged children were not negatively affected by the subsidy. The null results are also consistent with recent studies which show that families do not adjust their investments in children in response to either transitory income shocks (Carneiro/Ginja, 2016) or to unrestricted income transfers (e.g., see Heckman/Mosso, 2014).

23 Unfortunately, we do not have information on pre-birth earnings for mothers of children born in 2011 and therefore cannot provide evidence on the effects of the home care subsidy on childcare choices by maternal pre-birth incomes. 


\subsection{Robustness checks}

To corroborate the validity of our main results, we perform a number of additional robustness checks that go beyond the different regression specifications already presented in Sections 5.1 and 5.2. We focus on the two administrative datasets which allow us to perform a variety of tests due to the large number of observations and longer observation periods.

We begin with the employment outcomes in Table 6. Panel A replicates our baseline specification for comparison. To account for changes in employment trends that affect mothers giving birth in spring and autumn differently, we perform several robustness checks to test the sensitivity of our modelling choices, as displayed in Panel B. We begin by estimating a standard DiD model without any covariates. Furthermore, we estimate a DiDisc model with separate linear time trends for autumn and spring birth fully interacted with birth cohort dummies. As can be seen, the results do not change significantly compared to the baseline, but the standard errors more than double in the DiDisc specification. As another check, we add group-specific linear and quadratic time trends. If the treatment and control groups were on different time trends prior to the reform, including these time trends would change the estimation results. Overall, the results presented in Panel B show that these modelling choices do not affect our results.

In Panel C, we evaluate the sensitivity of our results with respect to changes in the observation window. Due to some measurement error in children's expected date of birth in the employment data (see Section 3), we now exclude all children born in the months of July and August to avoid misclassification; our point estimates hardly change. Next, we make the treated and control groups more similar by narrowing the observation window from 10 to 6 months, whilst still excluding mid-July to mid-August as in our baseline specification. Again, the results are almost identical to our baseline specifications.

In Panel D, we address concerns that the introduction of a legal entitlement to a slot in subsidised care might confound our results. In a placebo test, we use 2011 as our treatment year which pretends that children born in autumn 2011 are the treatment group. All children born in 2011 became legally entitled to a slot in public childcare on 1 August 2013, which was after the children's second birthday for children born in spring 2011 and before that birthday for children born in autumn 2011. This pattern is similar to the difference between children in our treatment and our control group, for both of whom the legal entitlement also came into force on 1 August 2013. As the children born in 2011 were, however, not eligible for the home care subsidy, the placebo analysis isolates differences that stem from becoming entitled before or after a birthday. Panel D shows no differences between these two groups, i.e., the placebo effects are all small and not significantly different from zero. We thus conclude that the introduction of a legal entitlement to a slot in subsidised care does not drive our 
results.

To finally check whether the top-coding of income affects our estimations, we exclude all women from our sample whose income was top-coded in any year, see Panel E. Again, this sample restriction barely affects our estimates.

We cannot perform as many robustness checks with the school entrance examinations data as we can only use children born in July or August for this analysis. This data limitation rules out running DiDisc models or further narrowing the observation window. Nevertheless, we can run a very limited DiD model with no control variables, add linear and quadratic groupspecific time trends, and run a placebo test in the pre-reform year to test the common trends assumption. We report the results in Table A.7. The coefficients presented for our main outcomes in Panel A pass the checks and confirm our main conclusion of no effect of the home care subsidy on children's skill development at age six. Similarly, Panel B presents additional evidence for outcomes measures collected in a non-standardised way. The coefficients again indicate that the subsidy did not affect children's speech, motor skill difficulties, or paediatricians' recommendations for additional support needs. 


\section{Windfall gains from the subsidy}

So far we have shown that 60 percent of eligible families received the home care subsidy at some point, and that the subsidy had very small effects on employment outcomes, childcare choices and children's development. The large difference between the take-up rates and the effects on employment and childcare choices indicates substantial windfall gains, i.e., that many recipients of the subsidy did not change their behaviour regarding employment and childcare choices. For this reason, this section investigates further who benefited from the subsidy. Along the lines of Boockmann et al. (2012), we define a windfall gain from the subsidy as a family receiving the subsidy, but not changing employment decisions or childcare choices. To estimate such windfall gains, we will compare the proportion of families who received the subsidy to the proportion of families who changed their behaviour due to the subsidy. If more families receive the subsidy than change their behaviour, some receiving families did not change their behaviour and hence a windfall gain occurred. We examine windfall gains separately with respect to maternal employment and attendance of subsidised childcare.

To investigate the windfall gains regarding maternal employment, we focus on the share of mothers who ever worked over the three years after giving birth. As this outcome is measured over a period of time, we compare the corresponding employment effects with the share of families who ever received the subsidy over these three years. ${ }^{24}$ As for childcare choices, we measure the effects of the subsidy on the probability to attend subsidised childcare at the time of the interview. To estimate windfall gains, we thus compare the effects with the share of families receiving the subsidy at the time of the interview.

Table 7 presents the results. With respect to windfall gains from employment, Panel A shows that the proportion of recipients amounts to 59.4 percent, and a comparison with the estimated effect on the likelihood of returning to the labour market (-1.4 percentage points) implies windfall gains as large as 98 percent of the subsidy. This calculation could overstate windfall gains as it does not take into account whether mothers shifted the timing of their return to employment after child birth. We therefore also compare the average effect on days in employment to the average days in subsidy receipt. As eligible families received the subsidy on average for about 360 days $^{25}$ and eligible mothers were employed for 13.5 days less, this comparison implies similar windfall gains of 96 percent.

\footnotetext{
${ }^{24}$ We report the take-up rates for the same sample as in the employment data, i.e., we restrict the sample to first-time mothers not receiving social assistance.

25 Alt et al. (2015: p.59) present administrative data that shows that, conditional on subsidy receipt, the average granted duration of receipt is 19.8 months. Given that $40.6 \%$ of families in our calculation never use the subsidy (as displayed in Table 6), the weighted average duration of receipt for all eligible families is 11.8 months or roughly 360 days.
} 
With respect to childcare choices, Panel A shows that 53.5 percent of eligible families received the subsidy at the time of the interview. Comparing this share with the estimated effects on the probability to use subsidised childcare (-5.3 percentage points) yields that around 90 percent of the home care subsidy accrued as windfall gains to families who would not have used subsidised childcare anyway. Overall, almost the entire expenditures on the childcare subsidy accrued as windfall gains to families that would not have used subsidised childcare anyway.

Proponents of home care subsidies might still argue that they are beneficial from a purely fiscal perspective if the savings on subsidised childcare outweigh the deadweight loss, which the windfall gains to the families impose from this fiscal perspective. The average monthly total fiscal cost per slot for children aged three and below in formal childcare amounted to 620 Euros. $^{26}$ Given the initial home care subsidy of 100 Euros, the savings on childcare expenditures then outweigh the expenditures for the home care subsidy only if one out of six families that receive the subsidy does no longer use childcare. This corresponds to a situation with windfall gains of up to 83 percent. As the actual average share of windfall gains is in the order of 90 percent at the time of the survey, the subsidy imposes a net fiscal burden. Moreover, this calculation provides a lower bound of the fiscal burden as it ignores mothers' payroll taxes, their social security contributions, the increase of the subsidy to 150 Euros in August 2014, and the marginal costs of public funds.

Table 7 additionally reports the take-up rates for subgroups for which we were able to estimate the effects of the home care subsidy on maternal employment and childcare choices. Panel B shows that families where the mother holds a tertiary degree are less likely to ever receive the subsidy (46.7\%) compared to families with non-university educated mothers (69.8\%). Combined with our point estimates on employment, these values imply that 98 percent of the subsidy accrued as windfall gains for both groups. Slightly smaller windfall gains emerge for childcare choices (see last column), though the gains are still substantial on the order of 88-90 percent. Further, we investigate differences by migration background in Panel C. Somewhat surprisingly, our analysis reveals no differences between families with and without migration background. Thus, both native and non-native families seem to have benefited equally from windfall gains. Taken together, our analysis shows that the share of the subsidy paid out as windfall to families that would not use subsidised childcare anyway was similar across socioeconomic groups.

The different shares of families receiving the home care subsidy across groups imply that the subsidy acts as an income transfer, which affected the distribution of income between fami-

\footnotetext{
26 We base our calculations on Haider/Schmiedel (2012). One third of children in subsidised childcare attended publicly run childcare centres, and the remaining two thirds attended childcare run by other providers, e.g. churches. For both types of providers, the annual costs per child below age 3 amounted to roughly 9,900 Euros. The government covered $81 \%$ of these costs for publicly run centres and $73 \%$ for centres run by other providers. The monthly average costs to the government for each slot and month hence amounted to 620 Euros.
} 
lies. This result raises the question which types of families benefited most. To this end, Table 8 reports take-up of the subsidy by household's pre-birth income and documents that takeup of the subsidy is hump-shaped: Whereas 60 percent of households in the lowest decile receive the subsidy, the share of recipients increases up to 77 percent in the fourth decile and drops steadily as income increases further. In the highest decile, 43 percent of families receive the subsidy. The subsidy hence does not transfer income to the families with the lowest prebirth incomes, but rather to families with lower medium pre-birth incomes. Looking at single parents and two-parent families separately confirms this pattern as 64 percent of the twoparent families ever receive the subsidy compared to only 39 percent of the single parents. Thus, the subsidy transferred income towards families who would not have used childcare anyway, and in particular towards families in the middle part of the income distribution. ${ }^{27}$

\footnotetext{
27 Additionally, Table A.8 splits the sample by mothers' and fathers' pre-birth earnings. Conditional on fathers' earnings, take-up of the home care subsidy is similar for families with mothers in the first and second earnings tertile and substantially lower among families with mothers in the highest tertile. Conditional on mothers' earnings, take-up is somewhat higher when the father earns a medium income. We cannot calculate windfall gains for these subgroups, because the employment data does not identify couples and the KiBS data does not include pre-birth earning for all years.
} 


\section{Conclusion}

This paper investigates the effects of the introduction of a home care subsidy in Germany in 2013 on maternal employment, childcare choices, and children's development. We make three major contributions to the literature. First, we use social security records on employment alongside detailed household survey data on take-up and on childcare choices to examine the effects of the subsidy on maternal employment and childcare arrangements. Second, we examine how the subsidy affects children's skill development using administrative data from mandatory school entrance examinations conducted at age six. Third, we combine the results on employment and childcare choices with the take-up of the subsidy to examine the extent and beneficiaries of potential windfall gains from the subsidy.

To estimate the effects of the subsidy, we exploit a date of birth cut-off in eligibility to the subsidy within a DiD design to remove seasonal patterns in the outcomes. Our results demonstrate that the introduction of the subsidy hardly affected maternal employment, decreased enrolment in subsidised childcare, but did not children's development despite substantial take-up. Our findings for maternal employment and childcare are consistent with prior results, though our results on child development at age six differ from the findings by Gathmann/Sass (2018) who examine outcomes between ages two and three. These differences may be explained by differences with respect to the social and institutional setting, the underlying data sources, and potential fade-out of effects.

The substantial gap between the treatment effects and take-up of the subsidy implies that at least nine out of ten recipients did not adjust their behaviour. The subsidy hence accrued almost completely as windfall gains to families who would not have used subsidised childcare even without the subsidy. We show that the windfall gains accrued similarly to all groups of recipients, although the socio-economic groups differ in their take-up rates pointing towards a distributional impact of the subsidy as an income transfer. Take-up of the subsidy was highest among families with lower medium pre-birth earnings, but substantially lower among the families with the lowest pre-birth incomes. Furthermore, take-up was lower among single parents than among two-parent families. The home care subsidy hence transferred income towards couples with lower to medium incomes, but benefited single mothers less than couples.

Taken together, the home care subsidy created substantial windfall gains, but did little else. The windfall gains can either be interpreted as an income transfer to specific families or as a deadweight loss assuming that the subsidy aimed at reducing subsidised childcare attendance. The income transfer did not accrue to those families with the least economic resources, which would appear to be the most natural target group. And when interpreting the windfall gains as a deadweight loss, a back-of-the-envelope calculation implies that the 
subsidy imposes a net fiscal burden. As our evidence is consistent with findings from previous studies, policymakers who consider introducing a similar cash-for-care policy should strongly reconsider whether spending the same resources on alternative uses, such as expanding high-quality child support programmes for families with few resources, may achieve more favourable outcomes for both mothers and their children. 


\section{References}

Alt, Christian; Bethmann, Arne; Gedon, Benjamin; Hubert, Sandra; Hüsken, Katrin; Lippert, Kerstin (2018): Kinderbetreuungsstudie. Laengsschnittdatensatz 2012-2016. Version: 1.

Alt, Christian; Hubert, Sandra; Lippert, Kerstin; Steinberg, Hannah (2015): Datenbericht Betreuungsgeld. Deutsches Jugendinstitut: München.

Arguedas, Carmen; van Soest, Daan P. (2009): On reducing the windfall profits in environmental subsidy programs. In: Journal of Environmental Economics and Management, Vol. 58, No. 2, p. 192-205.

Baker, Michael; Gruber, Jonathan; Milligan, Kevin (2019): The long-run impacts of a universal child care program. In: American Economic Journal: Economic Policy, Vol. 11, No. 3, p. $1-26$.

Bettinger, Eric; Hægeland, Torbjørn; Rege, Mari (2014): Home with Mom: The Effects of Stayat-Home Parents on Children's Long-Run Educational Outcomes. In: Journal of Labor Economics, Vol. 32, No. 3, p. 443-467.

Black, Sandra E.; Devereux, Paul J.; Løken, Katrine V.; Salvanes, Kjell G. (2014): Care or Cash? The Effect of Child Care Subsidies on Student Performance. In: Review of Economics and Statistics, Vol. 96, No. 5, p. 824-837.

Blau, David; Currie, Janet (2006): Preschool, Day Care, and Afterschool Care: Who's Minding the Kids? In: Handbook of the Economics of Education, Vol. 2, p. 1163-1278.

BMFSFJ (2016): Kindertagesbetreuung Kompakt. Ausbaustand und Bedarf2016. BMFSFJ (Federal Ministry for Family Affairs, Senior Citizens, Women and Youth), Berlin.

Bono, Emilia D.; Francesconi, Marco; Kelly, Yvonne; Sacker, Amanda (2016): Early Maternal Time Investment and Early Child Outcomes. In: The Economic Journal, Vol. 126, No. 596, p. F96-F135.

Boockmann, Bernhard; Zwick, Thomas; Ammermüller, Andreas; Maier, Michael (2012): Do Hiring Subsidies Reduce Unemployment Among Older Workers? Evidence From Two Natural Experiments. In: Journal of the European Economic Association, Vol. 10, No. 4, p. 735-764.

Carneiro, Pedro; Ginja, Rita (2016): Partial Insurance and Investments in Children. In: The Economic Journal, Vol. 126, No. 596, p. F66-F95.

Carta, Francesca; Rizzica, Lucia (2018): Early kindergarten, maternal labor supply and children's outcomes: Evidence from Italy. In: Journal of Public Economics, Vol. 158, p. 79102. 
Cascio, Elizabeth U. (2015): The promises and pitfalls of universal early education. In: IZA World of Labor, Vol. 116.

Cornelissen, Thomas; Dustmann, Christian; Raute, Anna; Schönberg, Uta (2018): Who benefits from universal child care? Estimating marginal returns to early child care attendance. In: Journal of Political Economy, Vol. 126, No. 6, p. 2356-2409.

Currie, Janet; Almond, Douglas (2011): Human Capital Development before Age Five. In: Handbook of Labor Economics, Vol. 4, Elsevier, p. 1315-1486.

Daseking, Monika; Petermann, Franz; Simon, Klaus (2011): Zusammenhang zwischen SOPESS-Ergebnissen und ärztlicher Befundbewertung. In: Das Gesundheitswesen, Vol. 73, No. 10, p. 660-667.

Drange, Nina (2015): Crowding out Dad? The Effect of a Cash-for-Care Subsidy on Family time Allocation. In: Nordic Journal of Political Economy, Vol. 40, No. 2, p. 1-29.

Drange, Nina; Havnes, Tarjei (2018): Child Care Before Age Two and the Development of Language and Numeracy: Evidence from a Lottery. In: Journal of Labor Economics, Vol. 37, p. 581-620.

Duncan, Alan; Giles, Christopher (1996): Should We Subsidise Pre-School Childcare, and If So, How? In: Fiscal Studies, Vol. 17, No. 3, p. 39-61.

Duvander, Ann-Zofie; Ellingsæter, Anne Lise (2016): Cash for childcare schemes in the Nordic welfare states: diverse paths, diverse outcomes. In: European Societies, Vol. 18, No. 1, p. 70-90.

Eydal, Guðnỳ Björk; Rostgaard, Tine (2011): Gender Equality Revisited -- Changes in Nordic Childcare Policies in the 2000s. In: Social Policy \& Administration, Vol. 45, No. 2, p. 161179.

FAZ (2013): Die Panne mit dem Stichtag. 03-08-2013.

FAZ (2012): Zeigt her eure Krippen! 10-11-2012.

Felfe, Christina; Lalive, Rafael (2018): Does early child care affect children's development? In: Journal of Public Economics, Vol. 159, p. 33-53.

Felfe, Christina; Rainer, Helmut; Saurer, Judith (2019): Why Birthright Citizenship Matters for Immigrant Children: Short- and Long-Run Impacts on Educational Integration. In: Journal of Labor Economics, p. forthcoming.

Felfe, Christina; Zierow, Larissa (2018): From dawn till dusk: Implications of full-day care for children's development. In: Labour Economics, Vol. 55, p. 259-281. 
Fort, Margherita; Ichino, Andrea; Zanella, Giulio (2020): Cognitive and Noncognitive Costs of Day Care at Age 0-2 for Children in Advantaged Families. In: Journal of Political Economy, Vol. 128, No. 1, p. 158-205.

Gathmann, Christina; Sass, Björn (2018): Taxing Childcare: Effects on Childcare Choices, Family Labor Supply, and Children. In: Journal of Labor Economics, Vol. 36, No. 3, p. 665-709.

Giuliani, Giuliana; Duvander, Ann Zofie (2017): Cash-for-care policy in Sweden: An appraisal of its consequences on female employment. In: International Journal of Social Welfare, Vol. 26, No. 1, p. 49-62.

Haan, Peter; Simmler, Martin (2018): Wind electricity subsidies - A windfall for landowners? Evidence from a feed-in tariff in Germany. In: Journal of Public Economics, Vol. 159, p. $16-32$.

Haider, Carsten; Schmiedel, Sven (2012): Finanzen der Kindertageseinrichtungen in freier Trägerschaft 2010.

Heckman, James J.; Mosso, Stefano (2014): The Economics of Human Development and Social Mobility. In: Annual Review of Economics, Vol. 6, No. 1, p. 689-733.

Hsin, Amy; Felfe, Christina (2014): When Does Time Matter? Maternal Employment, Children's Time With Parents, and Child Development. In: Demography, Vol. 51, No. 5, p. 1867-1894.

Huebener, Mathias; Kuehnle, Daniel; Spiess, C. Katharina (2019): Parental Leave Policies and Socio-Economic Gaps in Child Development: Evidence from a Substantial Benefit Reform Using Administrative Data. In: Labour Economics, Vol. 61, p. 101754.

Jacobebbinghaus, Peter; Seth, Stefan (2007): The German integrated employment biographies sample IEBS. In: Schmollers Jahrbuch, Vol. 127, No. 2, p. 335-342.

Kleven, Henrik Jacobsen; Kreiner, Claus Thustrup (2006): The marginal cost of public funds: Hours of work versus labor force participation. In: Journal of Public Economics, Vol. 90, No. 10-11, p. 1955-1973.

Kosonen, Tuomas (2014): To Work or Not to Work? The Effect of Childcare Subsidies on the Labour Supply of Parents. In: The B.E. Journal of Economic Analysis \& Policy, Vol. 14, No. 3.

Kreyenfeld, Michaela; Hank, Karsten (2000): Does the availability of child care influence the employment of mothers? Findings from Western Germany. In: Population Research and Policy Review, Vol. 19, No. 4, p. 317-337.

Kuehnle, Daniel; Oberfichtner, Michael (2020): Does Starting Universal Childcare Earlier Influence Children's Skill Development? In: Demography, Vol. 57, No. 1, p. 61-98. 
Løken, Katrine V.; Mogstad, Magne; Wiswall, Matthew (2012): What linear estimators miss: The effects of family income on child outcomes. In: American Economic Journal: Applied Economics, Vol. 4, No. 2, p. 1-35.

Müller, Dana; Strauch, Katharina (2017): Identifying mothers in administrative data. In: FDZMethodenreport, , No. 13/2017.

Naz, Ghazala (2004): The Impact of Cash-Benefit Reform on Parents' Labour Force Participation. In: Journal of Population Economics, Vol. 17, No. 2, p. 369-383.

OECD (2017): Starting Strong 2017. Key OECD Indicators on Early Childhood Education and Care. OECD, Paris.

OECD (2016): Who uses childcare? Background brief on inequalities in the use of formal early childhood education and care (ECEC) among very young children. OECD, Paris.

Oldenhage, Marijke; Daseking, Monika; Petermann, Franz (2009): Erhebung des Entwicklungsstandes im Rahmen der ärztlichen Schuleingangsuntersuchung. In: Das Gesundheitswesen, Vol. 71, No. 10, p. 638-647.

Schnabel, Claus (2016): United, Yet Apart? A Note on Persistent Labour Market Differences between Western and Eastern Germany. In: Jahrbücher für Nationalökonomie und Statistik, Vol. 236, No. 2, p. 157-179.

Schönberg, Uta; Ludsteck, Johannes (2014): Expansions in Maternity Leave Coverage and Mothers' Labor Market Outcomes after Childbirth. In: Journal of Labor Economics, Vol. 32, No. 3, p. 469-505.

Schøne, Pål (2004): Labour Supply Effects of a Cash-for-Care Subsidy. In: Journal of Population Economics, Vol. 17, No. 4, p. 703-727.

Spiess, C. Katharina; Kreyenfeld, Michaela; Wagner, Gert G. (2003): A forgotten issue: Distributional effects of day care subsidies in Germany. In: European Early Childhood Education Research Journal, Vol. 11, No. 2, p. 159-175.

Thomsen, Ulrich; Ludsteck, Johannes; Schmucker, Alexandra (2018): Skilled or unskilled Improving the information on qualification for employee data in the IAB Employee Biography. In: FDZ-Methodenreport, , No. 09/2018.

Thoresen, Thor O.; Vattø, Trine E. (2019): An up-to-date joint labor supply and child care choice model. In: European Economic Review, Vol. 112, p. 51-73.

Xing, Jianwei; Leard, Benjamin; Li, Shanjun (2019): What Does an Electric Vehicle Replace? Working Paper 25771, National Bureau of Economic Research. 


\section{Appendix}

\section{Figures and Tables}

Figure 1: Search intensity for cut-off rule

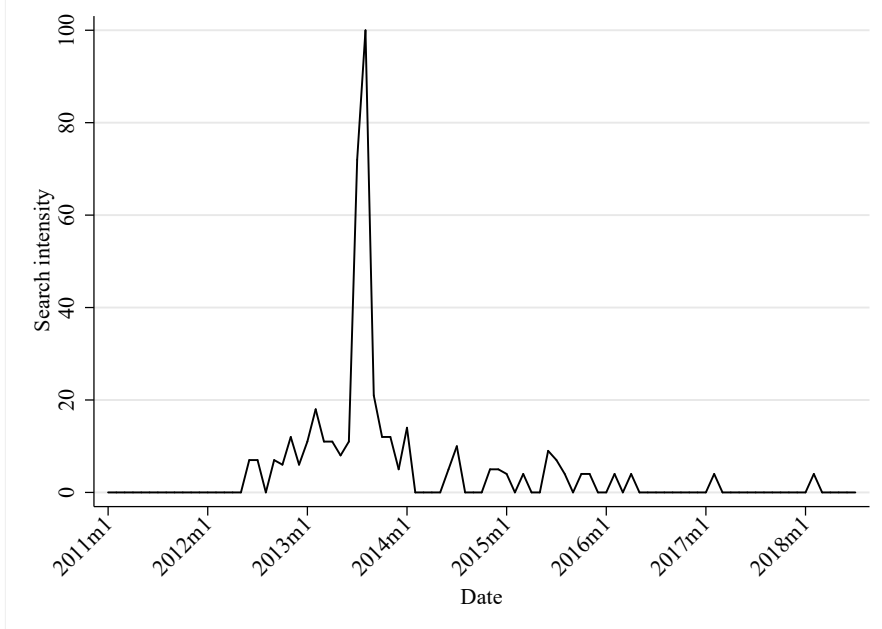

Notes: This figure shows the search intensity for cut-off rules for the home care subsidy (Betreuungsgeld Stichtag).

Source: Source: Google Trends. 
Figure 2: Take-up rate of home care subsidy

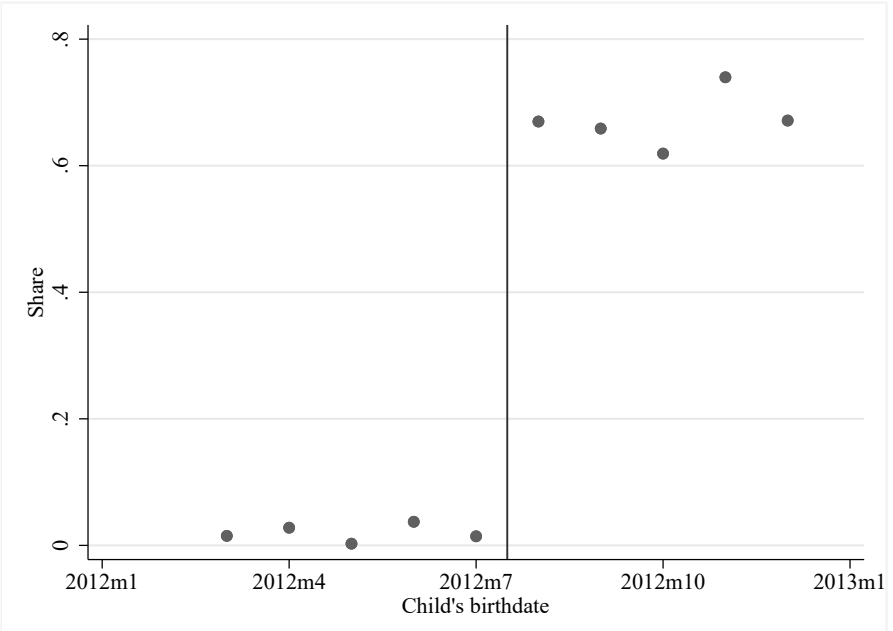

Notes: This figure shows the take-up rate by birth month for children born in 2012 using cross-sectional survey weights.

Source: Own calculations based on KiBS. CIAB 


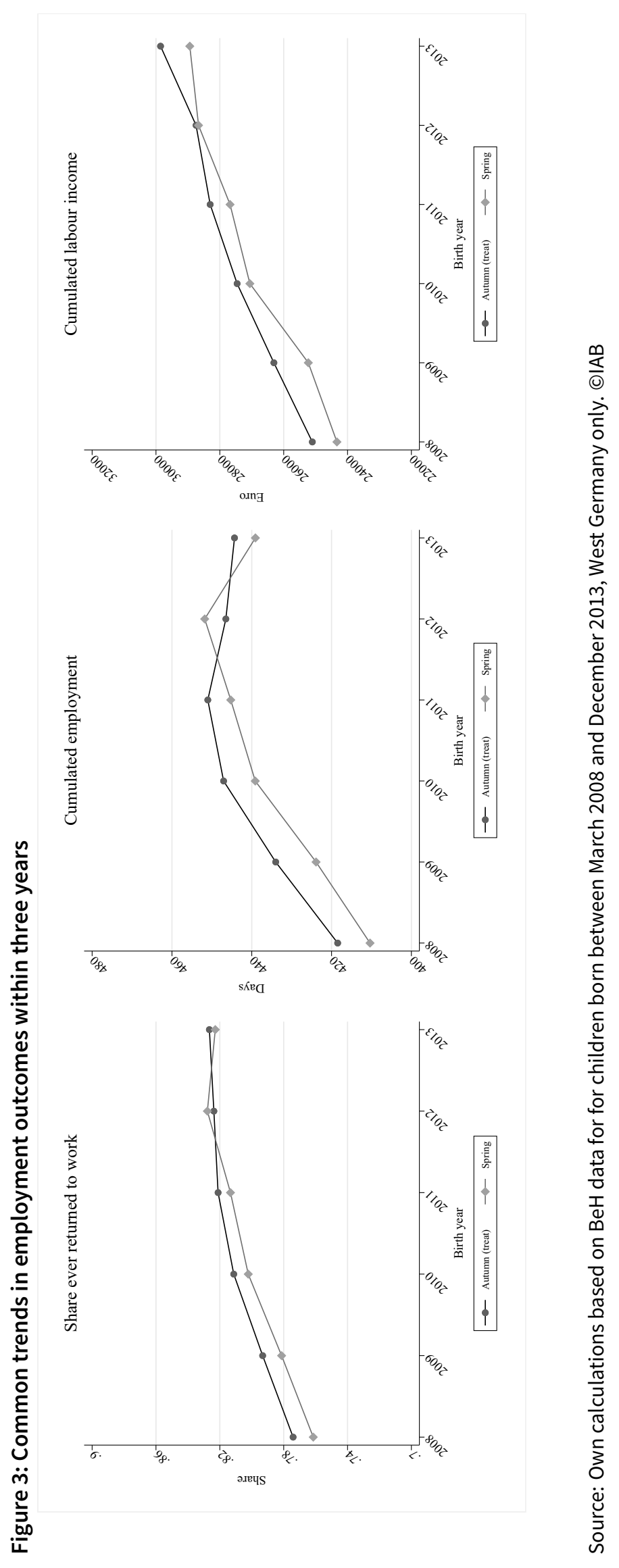

IAB-Discussion Paper 25|2020 
Figure 4: Reduced form relationship for children's outcomes

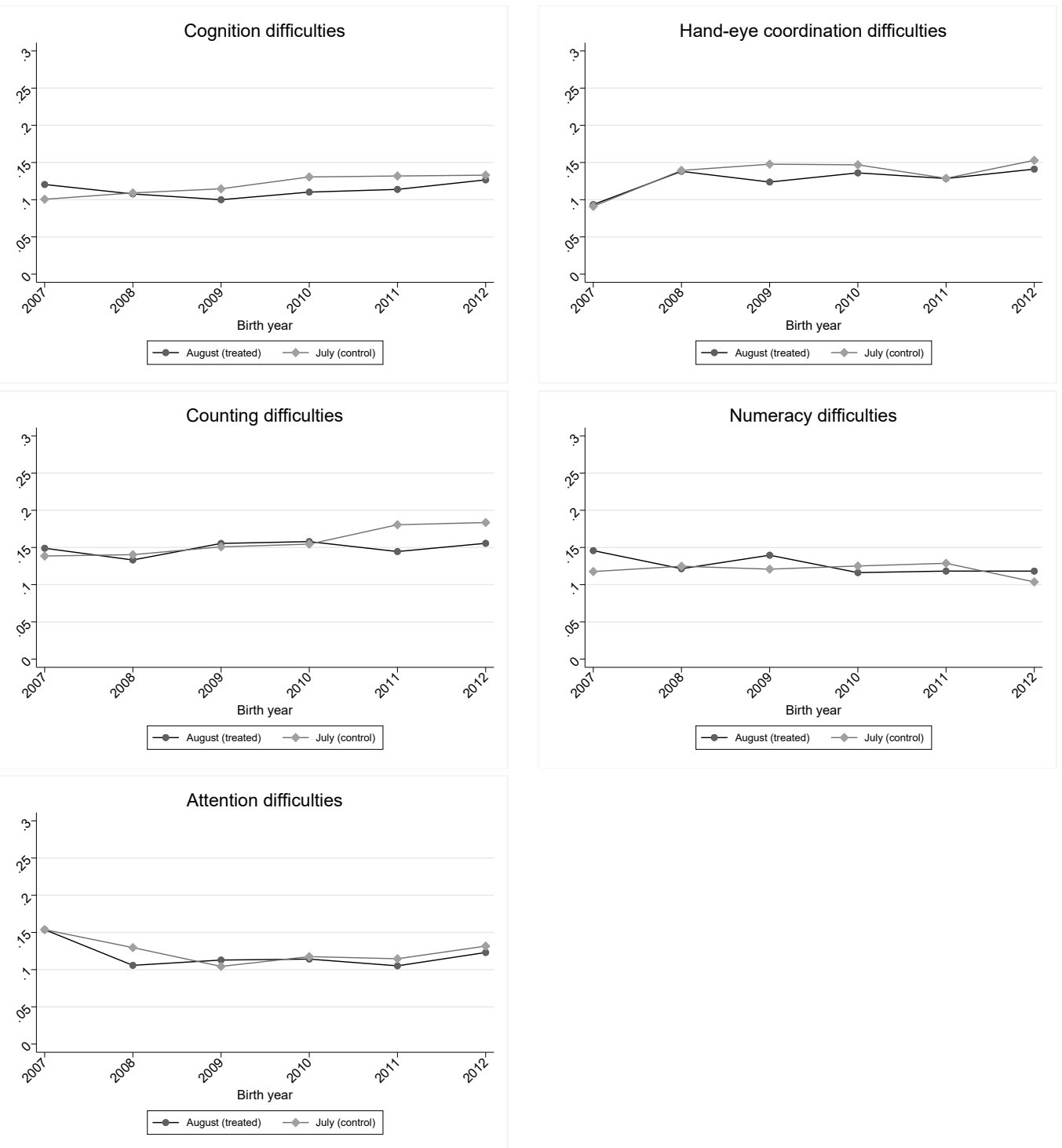

Source: Own calculations based on school entrance examinations data for children born between in July and August between 2007 and 2012, Schleswig-Holstein only. OIAB 
Table 1: Descriptive statistics - childcare \& employment data

\begin{tabular}{|c|c|c|c|c|c|c|c|c|}
\hline \multirow[b]{2}{*}{ Variable } & \multirow{2}{*}{$\begin{array}{l}\text { Overall } \\
\text { Mean }\end{array}$} & \multicolumn{2}{|c|}{ Spring } & \multicolumn{2}{|c|}{ Autumn } & \multirow[b]{2}{*}{ Diff. } & \multirow[b]{2}{*}{$p$-value } & \multirow[b]{2}{*}{ Std.Diff } \\
\hline & & Mean & SD & Mean & SD & & & \\
\hline \multicolumn{9}{|l|}{ Panel A: Employment data $(\mathrm{N}=45,014)$} \\
\hline Age at birth & 30.11 & 30.08 & 4.19 & 30.14 & 4.17 & -0.052 & 0.062 & -0.013 \\
\hline Daily wage prior to birth & 79.70 & 78.92 & 38.64 & 80.46 & 39.27 & -1.542 & 0.000 & -0.040 \\
\hline Full time & 0.78 & 0.78 & 0.41 & 0.78 & 0.41 & 0.003 & 0.339 & 0.007 \\
\hline No tertiary degree & 0.72 & 0.73 & 0.45 & 0.72 & 0.45 & 0.001 & 0.723 & 0.002 \\
\hline Tertiary degree & 0.24 & 0.24 & 0.42 & 0.24 & 0.43 & -0.003 & 0.305 & -0.007 \\
\hline German citizen & 0.92 & 0.92 & 0.28 & 0.92 & 0.28 & 0.001 & 0.689 & 0.003 \\
\hline \multicolumn{9}{|l|}{ Panel B: Childcare data } \\
\hline \multicolumn{9}{|l|}{ Mother characteristics $(\mathrm{N}=4,879)$} \\
\hline Mother's age at birth & 33.25 & 33.14 & 5.14 & 33.37 & 4.94 & -0.231 & 0.287 & -0.046 \\
\hline Tertiary degree & 0.40 & 0.43 & 0.50 & 0.37 & 0.48 & 0.062 & 0.003 & 0.127 \\
\hline Wage pre birth & 1676.77 & 1727.55 & 1126.41 & 1626.12 & 1006.58 & 101.430 & 0.040 & 0.095 \\
\hline Married & 0.90 & 0.89 & 0.31 & 0.90 & 0.30 & -0.006 & 0.680 & -0.018 \\
\hline \multicolumn{9}{|c|}{ Partner characteristics (conditional on having a partner, $\mathrm{N}=4,736$ ) } \\
\hline Tertiary degree & 0.41 & 0.43 & 0.50 & 0.38 & 0.49 & 0.051 & 0.018 & 0.104 \\
\hline Wage pre birth & 2647.07 & 2734.06 & 1442.62 & 2558.17 & 1513.39 & 175.887 & 0.014 & 0.119 \\
\hline \multicolumn{9}{|l|}{ Household characteristics $(\mathrm{N}=4,879)$} \\
\hline Both parents born in Germany & 0.74 & 0.76 & 0.43 & 0.73 & 0.44 & 0.026 & 0.165 & 0.060 \\
\hline At least one parent born outside Germany & 0.26 & 0.24 & 0.43 & 0.27 & 0.44 & -0.026 & 0.165 & -0.060 \\
\hline At home: German main language & 0.83 & 0.85 & 0.36 & 0.81 & 0.39 & 0.037 & 0.024 & 0.097 \\
\hline At home: Non-German main language & 0.17 & 0.15 & 0.36 & 0.19 & 0.39 & -0.037 & 0.024 & -0.097 \\
\hline Number of children & 1.95 & 2.00 & 0.91 & 1.91 & 0.91 & 0.089 & 0.024 & 0.098 \\
\hline Living with partner (if in relationship) & 0.99 & 0.99 & 0.10 & 0.98 & 0.12 & 0.005 & 0.261 & 0.050 \\
\hline
\end{tabular}

Source childcare data: Own calculations based on KiBS for children born between March 2012 and December 2012, West Germany only, using cross-sectional survey weights. Source employment data: Own calculations based on BeH data for children born between March 2012 and December 2012, West Germany only. CIAB 
Table 2: Descriptive statistics - school entrance examinations data

\begin{tabular}{lcccccccc}
\hline & Overall & \multicolumn{2}{c}{ Spring } & \multicolumn{2}{c}{ Autumn } & & & \\
Variable & Mean & Mean & SD & Mean & SD & Diff. & p-value & Std.Diff \\
\hline Age at testing (in years) & 6.54 & 6.57 & 0.21 & 6.51 & 0.22 & 0.063 & 0.000 & 0.294 \\
Female & 0.45 & 0.45 & 0.50 & 0.45 & 0.50 & -0.006 & 0.794 & -0.012 \\
Mother - highest education level & & & & & & & & \\
$\quad$ Missing & 0.23 & 0.23 & 0.42 & 0.24 & 0.43 & -0.013 & 0.487 & -0.031 \\
$\quad$ Upper secondary & 0.34 & 0.35 & 0.48 & 0.32 & 0.47 & 0.025 & 0.236 & 0.052 \\
$\quad$ Lower secondary & 0.43 & 0.42 & 0.49 & 0.44 & 0.50 & -0.012 & 0.591 & -0.024 \\
Mother - country of origin & & & & & & & & \\
$\quad$ Missing & 0.22 & 0.23 & 0.42 & 0.22 & 0.41 & 0.012 & 0.504 & 0.030 \\
$\quad$ Other country & 0.15 & 0.15 & 0.35 & 0.16 & 0.36 & -0.012 & 0.442 & -0.034 \\
$\quad$ Germany & 0.63 & 0.63 & 0.48 & 0.63 & 0.48 & -0.000 & 0.997 & -0.000 \\
Father - highest education level & & & & & & & & \\
$\quad$ Missing & 0.30 & 0.31 & 0.46 & 0.29 & 0.45 & 0.023 & 0.254 & 0.050 \\
$\quad$ Upper secondary & 0.30 & 0.30 & 0.46 & 0.31 & 0.46 & -0.009 & 0.662 & -0.019 \\
$\quad$ Lower secondary & 0.40 & 0.39 & 0.49 & 0.40 & 0.49 & -0.014 & 0.510 & -0.029 \\
Father - highest education level & & & & & & & & \\
$\quad$ Missing & 0.24 & 0.26 & 0.44 & 0.23 & 0.42 & 0.020 & 0.282 & 0.048 \\
$\quad$ Other country & 0.14 & 0.14 & 0.34 & 0.14 & 0.35 & -0.001 & 0.952 & -0.003 \\
$\quad$ Germany & 0.62 & 0.61 & 0.49 & 0.63 & 0.48 & -0.020 & 0.363 & -0.040 \\
Main language spoken at home & & & & & & & & \\
$\quad$ Missing & 0.06 & 0.06 & 0.24 & 0.05 & 0.22 & 0.007 & 0.519 & 0.028 \\
$\quad$ German & 0.77 & 0.78 & 0.41 & 0.77 & 0.42 & 0.012 & 0.531 & 0.028 \\
$\quad$ Foreign language & 0.08 & 0.08 & 0.28 & 0.07 & 0.26 & 0.012 & 0.326 & 0.043 \\
$\quad$ Bilingual & 0.09 & 0.08 & 0.27 & 0.11 & 0.31 & -0.030 & 0.021 & -0.103 \\
\hline$\quad$ N & 2052 & 975 & & 1077 & & & & \\
\hline
\end{tabular}

Notes: Sample based on districts that provide information on standardised SOPESS outcomes. Source: Own calculations based on school entrance examinations data for children born between in July or August 2012, Schleswig-Holstein only. CIAB 
Table 3: Employment outcomes - main results

\begin{tabular}{|c|c|c|c|c|}
\hline & $N$ & $\begin{array}{c}\text { Ever returned } \\
\text { to work }\end{array}$ & $\begin{array}{l}\text { Cumulated } \\
\text { employment }\end{array}$ & $\begin{array}{c}\text { Cumulated } \\
\text { labour income }\end{array}$ \\
\hline \multirow[t]{2}{*}{ Panel A: Baseline } & \multirow[t]{3}{*}{506919} & $-0.014^{* * *}$ & $-13.511^{* * *}$ & $-907.011^{* * *}$ \\
\hline & & $(0.003)$ & $(2.277)$ & $(197.623)$ \\
\hline Mean 2012 Spring & & 0.828 & 452 & 28668 \\
\hline \multicolumn{5}{|l|}{ Panel B: By Education } \\
\hline \multirow[t]{2}{*}{ No tertiary degree } & \multirow[t]{3}{*}{377768} & $-0.014^{* * *}$ & $-14.884^{* * *}$ & $-873.894^{* * *}$ \\
\hline & & $(0.003)$ & $(2.690)$ & $(205.364)$ \\
\hline Mean 2012 Spring & & 0.821 & 447 & 24542 \\
\hline \multirow[t]{2}{*}{ Tertiary degree } & \multirow[t]{3}{*}{109760} & -0.008 & $-8.808^{*}$ & $-1160.849^{* *}$ \\
\hline & & $(0.005)$ & $(4.527)$ & $(538.689)$ \\
\hline Mean 2012 Spring & & 0.859 & 478 & 43265 \\
\hline \multicolumn{5}{|l|}{ Panel C: By Citizenship } \\
\hline \multirow[t]{2}{*}{ Foreign } & \multirow[t]{3}{*}{40875} & -0.012 & -12.392 & -825.005 \\
\hline & & $(0.011)$ & $(8.200)$ & (689.169) \\
\hline Mean 2012 Spring & & 0.753 & 393 & 26322 \\
\hline German & 466044 & $\begin{array}{c}-0.014^{* * *} \\
(0.003)\end{array}$ & $\begin{array}{c}-13.591^{* * *} \\
(2.368)\end{array}$ & $\begin{array}{c}-923.992^{* * *} \\
(206.055)\end{array}$ \\
\hline Mean 2012 Spring & & 0.835 & 457 & 28881 \\
\hline
\end{tabular}

Notes: Outcomes are measured 36 months after birth. Cumulated employment is measured in days, cumulated labour income in EUR. Controls in $X_{i}$ are district fixed effects, age at birth dummies $(<25,25-30,30-35,30-40,>40)$, wage prior to birth dummies ( $<20,20-40,40-60,60-80,80-100,100-120,>120)$, tertiary education (dummy), dummies for missing values in either. Robust standard errors in parentheses.

Sigificance tests for the differences between the group: Education: returned to work: $p=.36$, employment: $p=.25$, income: $p=.62$. Nationality: returned to work: $p=.87$, employment: $p=.89$, income: $p=.89$.

Significance levels: ${ }^{*} p<0.10,{ }^{* *} p<0.05,{ }^{* * *} p<0.01$.

Source: Own calculations based on BeH data for for children born between March 2008 and December 2013, West Germany only.@IAB 
Table 4: Childcare choices - main results

\begin{tabular}{|c|c|c|c|}
\hline & $\mathrm{N}$ & Subsidised provider & Standard Error \\
\hline Panel A: Baseline & 9104 & $-0.053^{*}$ & $(0.028)$ \\
\hline Mean 2012 Spring & & 0.470 & \\
\hline \multicolumn{4}{|l|}{ Panel B: Maternal education } \\
\hline No tertiary degree (take-up: 0.593 ) & 5138 & $-0.064^{*}$ & $(0.034)$ \\
\hline Mean 2012 Spring & & 0.370 & \\
\hline Tertiary degree (take-up: 0.334) & 3966 & -0.047 & $(0.050)$ \\
\hline Mean 2012 Spring & & 0.614 & \\
\hline \multicolumn{4}{|l|}{ Panel C: Main language at home } \\
\hline German (take-up: 0.477) & 7649 & -0.043 & $(0.031)$ \\
\hline Mean 2012 Spring & & 0.492 & \\
\hline Non-German (take-up: 0.564) & 1432 & $-0.117^{*}$ & $(0.063)$ \\
\hline Mean 2012 Spring & & 0.352 & \\
\hline \multicolumn{4}{|l|}{ Panel D: Parental country of origin } \\
\hline Both born in Germany (take-up: 0.497 ) & 7027 & -0.043 & $(0.033)$ \\
\hline Mean 2012 Spring & & 0.493 & \\
\hline At least one born abroad (take-up: 0.487) & 2069 & -0.082 & $(0.055)$ \\
\hline Mean 2012 Spring & & 0.398 & \\
\hline
\end{tabular}

Notes: $\mathrm{N}=9104$. Analyses using births march to december in 2011 and 2012 aged 12-36 months during the interview. Controls are maternal age at birth dummies ( $<25,25-30,30-35,35-40,>40)$, survey year dummies, federal state fixed effects, maternal tertiary education (dummy), children's age in month dummies (12-18,18-24,2430,30-36). Dummies for missing values in any control variable are included as well. Cluster robust (on mother's level) standard errors in parentheses.

Significance levels: ${ }^{*} p<0.10,{ }^{* *} p<0.05,{ }^{* * *} p<0.01$.

Source: Own calculations based on KiBS for children born between March 2011 and December 2012, WestGermany only. CIAB 
Table 5: Children's outcomes - main results

\begin{tabular}{|c|c|c|c|c|c|c|c|}
\hline & \multirow[t]{2}{*}{ All } & \multicolumn{2}{|c|}{ Maternal education } & \multicolumn{2}{|c|}{ Main language at home } & \multicolumn{2}{|c|}{ Parental country of origin } \\
\hline & & Low & High & German & Non-German & $\begin{array}{l}\text { Both born } \\
\text { in Germany }\end{array}$ & $\begin{array}{l}\text { At least one } \\
\text { born abroad }\end{array}$ \\
\hline \multirow[t]{2}{*}{ Cognition difficulties } & -0.005 & -0.010 & -0.010 & -0.009 & 0.013 & 0.004 & -0.028 \\
\hline & $(0.018)$ & $(0.029)$ & $(0.024)$ & $(0.019)$ & $(0.082)$ & $(0.020)$ & $(0.045)$ \\
\hline Pre-reform mean & 0.133 & 0.162 & 0.088 & 0.119 & 0.219 & 0.113 & 0.193 \\
\hline \multirow[t]{2}{*}{ Hand-eye coordination difficulties } & -0.012 & -0.041 & 0.028 & -0.003 & 0.011 & -0.008 & -0.054 \\
\hline & $(0.019)$ & $(0.030)$ & $(0.027)$ & $(0.020)$ & $(0.079)$ & $(0.021)$ & $(0.047)$ \\
\hline Pre-reform mean & 0.153 & 0.206 & 0.095 & 0.137 & 0.192 & 0.135 & 0.220 \\
\hline \multirow[t]{2}{*}{ Attention difficulties } & -0.012 & -0.001 & -0.008 & -0.003 & -0.034 & -0.004 & -0.033 \\
\hline & $(0.018)$ & $(0.028)$ & $(0.027)$ & $(0.019)$ & $(0.072)$ & $(0.020)$ & $(0.043)$ \\
\hline Pre-reform mean & 0.132 & 0.143 & 0.112 & 0.130 & 0.151 & 0.120 & 0.160 \\
\hline \multirow[t]{2}{*}{ Counting difficulties } & -0.027 & -0.035 & -0.028 & $-0.042^{\star \star}$ & 0.107 & -0.027 & -0.061 \\
\hline & $(0.019)$ & $(0.030)$ & $(0.027)$ & $(0.020)$ & $(0.099)$ & $(0.020)$ & $(0.054)$ \\
\hline Pre-reform mean & 0.184 & 0.196 & 0.126 & 0.140 & 0.452 & 0.122 & 0.373 \\
\hline \multirow[t]{2}{*}{ Numeracy } & 0.002 & 0.014 & -0.032 & -0.002 & 0.016 & 0.005 & -0.003 \\
\hline & $(0.017)$ & $(0.027)$ & $(0.023)$ & $(0.017)$ & $(0.083)$ & $(0.018)$ & $(0.046)$ \\
\hline Pre-reform mean & 0.104 & 0.115 & 0.084 & 0.084 & 0.192 & 0.076 & 0.180 \\
\hline $\mathrm{N}$ & 10012 & 4784 & 2870 & 7917 & 677 & 7206 & 1995 \\
\hline
\end{tabular}

Notes: Controls are age at testing (dummies), child's gender, parents' education (dummies), maternal country of origin (dummies), language spoken at home (dummies), district $\mathrm{X}$ year fixed effects.

Significance levels: ${ }^{*} p<0.10,{ }^{* *} p<0.05,{ }^{* * *} p<0.01$.

Source: Own calculations based on school entrance examinations data for children born between in July or August between 2007 and 2012 , Schleswig-Holstein only. @IAB 
Table 6: Robustness checks

\begin{tabular}{|c|c|c|c|c|}
\hline & $\mathrm{N}$ & $\begin{array}{c}\text { Ever returned } \\
\text { to work }\end{array}$ & $\begin{array}{l}\text { Cumulated } \\
\text { employment }\end{array}$ & $\begin{array}{c}\text { Cumulated } \\
\text { labour income }\end{array}$ \\
\hline \multirow[t]{2}{*}{ Panel A: Baseline } & 506919 & $-0.014^{* * *}$ & $-13.511^{* * *}$ & $-907.011^{* * *}$ \\
\hline & & $(0.003)$ & $(2.277)$ & $(197.623)$ \\
\hline Mean 2012 Spring & & 0.828 & 452 & 28668 \\
\hline \multicolumn{5}{|l|}{ Panel B: Specification checks } \\
\hline \multirow[t]{2}{*}{ DiD } & 506919 & $-0.013^{* * *}$ & $-12.648^{* * *}$ & $-677.401^{* * *}$ \\
\hline & & $(0.003)$ & $(2.312)$ & $(229.431)$ \\
\hline \multirow[t]{2}{*}{ DiDisc } & 506919 & -0.010 & $-9.703^{*}$ & $-742.962^{*}$ \\
\hline & & $(0.006)$ & $(5.191)$ & $(449.229)$ \\
\hline \multirow[t]{2}{*}{ Linear } & 506919 & $-0.010^{* * *}$ & $-11.888^{* * *}$ & $-853.363^{* * *}$ \\
\hline & & $(0.003)$ & $(2.446)$ & $(213.857)$ \\
\hline \multirow[t]{2}{*}{ Quadratic } & 506919 & $-0.011^{* * *}$ & $-12.029^{* * *}$ & $-810.856^{* * *}$ \\
\hline & & $(0.003)$ & $(2.484)$ & $(216.321)$ \\
\hline \multicolumn{2}{|l|}{ Mean 2012 Spring } & 0.828 & 452 & 28668 \\
\hline \multicolumn{5}{|c|}{ Panel C: Observation period: births in... } \\
\hline \multirow[t]{2}{*}{ Juli and August excluded } & 443253 & $-0.015^{* * *}$ & $-14.692^{* * *}$ & $-916.254^{* * *}$ \\
\hline & & $(0.003)$ & $(2.436)$ & $(211.334)$ \\
\hline Mean 2012 Spring & & 0.829 & 453 & 28716 \\
\hline \multirow[t]{2}{*}{ May to october only } & 292160 & $-0.015^{* * *}$ & $-13.255^{* * *}$ & $-845.956^{* * *}$ \\
\hline & & $(0.004)$ & $(3.002)$ & $(260.605)$ \\
\hline Mean 2012 Spring & & 0.826 & 451 & 28599 \\
\hline \multicolumn{5}{|l|}{ Panel D: Placebo Treatment } \\
\hline \multirow[t]{2}{*}{ Placebo 2011} & 325604 & -0.004 & -2.955 & -144.233 \\
\hline & & $(0.003)$ & $(2.498)$ & $(213.493)$ \\
\hline Mean 2011 Spring & & 0.813 & 445 & 27681 \\
\hline \multicolumn{5}{|c|}{ Panel E: Excluding observations above the social security contribution threshold } \\
\hline \multirow[t]{2}{*}{ Below threshold } & 479700 & $-0.014^{* * *}$ & $-13.602^{* * *}$ & $-811.177^{* * *}$ \\
\hline & & $(0.003)$ & $(2.348)$ & $(186.495)$ \\
\hline Mean 2012 Spring & & 0.822 & 446 & 26145 \\
\hline
\end{tabular}

Notes: Outcomes are measured 36 months after birth. Cumulated employment is measured in days, cumulated labour income in EUR. Controls in $X_{i}$ are district fixed effects, age at birth dummies (<25,25-30,30-35,30-40,>40), daily wage prior to birth dummies (<20, 20-40, 40-60, 60-80, 80-100, 100-120, >120), tertiary education (dummy), dummies for missing values in either. Robust standard errors in parentheses.

Significance levels: ${ }^{*} p<0.10,{ }^{* *} p<0.05,{ }^{* * *} p<0.01$.

Source: Own calculations based on BeH data for for children born between March 2008 and December 2013, West Germany only. CIAB 


\section{Table 7: Windfall gains}

\begin{tabular}{|c|c|c|c|c|c|c|}
\hline & \multicolumn{3}{|c|}{ Employment } & \multicolumn{3}{|c|}{ childcare choices } \\
\hline & Ever take-up(\%) & effect(pp) & windfall gains & Current take-up (\%) & effect(pp) & windfall gains \\
\hline Panel A: All & 59.4 & -1.4 & $97.6 \%$ & 53.5 & -5.3 & $90.1 \%$ \\
\hline \multicolumn{7}{|c|}{ Panel B: By maternal education } \\
\hline No tertiary degree & 69.8 & -1.4 & $98.0 \%$ & 61.6 & -6.4 & $89.6 \%$ \\
\hline Tertiary degree & 46.7 & -0.8 & $98.3 \%$ & 41.5 & -4.7 & $88.7 \%$ \\
\hline \multicolumn{7}{|c|}{ Panel C: By migration background ${ }^{1}$} \\
\hline German & 57.3 & -1.4 & $97.6 \%$ & 52.6 & -4.3 & $91.8 \%$ \\
\hline Non-German & 66.7 & -1.2 & $98.2 \%$ & 56.0 & -8.2 & $85.4 \%$ \\
\hline
\end{tabular}

Notes: ${ }^{1}$ In the IAB data, migration background is measured as mother's citizenship whereas min the KiBS data, migration background is measured as whether at least one parent is born outside Germany.

Source: Childcare choices and take-up: Own calculations based on KiBS for children born between August 2012 and December 2013, West-Germany only, children aged 12-36 months, using cross-sectional survey weights.

Employment: Own calculations based on BeH data for for children born between March 2008 and December 2013, West Germany only. CIAB 
Table 8: Take-up of childcare allowance by household income prior to birth.

\begin{tabular}{lcccc}
\hline Income prior to birth & All & One child & Not on welfare & Single parent \\
\hline 1st decile & 0.613 & 0.613 & 0.677 & 0.431 \\
Observations & 272 & 125 & 188 & 61 \\
2nd decile & 0.648 & 0.615 & 0.643 & 0.258 \\
Observations & 278 & 130 & 217 & 30 \\
3rd decile & 0.705 & 0.584 & 0.687 & 0.615 \\
Observations & 308 & 147 & 269 & 9 \\
4th decile & 0.766 & 0.678 & 0.782 & 0.000 \\
Observations & 278 & 128 & 251 & 3 \\
5th decile & 0.682 & 0.679 & 0.670 & 0.521 \\
Observations & 294 & 132 & 268 & 4 \\
6th decile & 0.631 & 0.605 & 0.634 & 0.000 \\
Observations & 270 & 134 & 248 & 2 \\
7th decile & 0.556 & 0.501 & 0.557 & 0.000 \\
Observations & 275 & 148 & 255 & 1 \\
8th decile & 0.560 & 0.579 & 0.570 & 0.000 \\
Observations & 313 & 158 & 291 & 1 \\
9th decile & 0.547 & 0.471 & 0.529 & 0.000 \\
Observations & 292 & 148 & 266 & 1 \\
10th decile & 0.427 & 0.431 & 0.431 & 0.000 \\
Observations & 287 & 140 & 267 & 2 \\
\hline
\end{tabular}

Source: Own calculations based on KiBS for children born between August 2012 and December 2013, WestGermany only, children aged 12-36 months, using cross-sectional survey weights. CIAB 


\section{Appendix A: Supplementary material}

Figure A.1: Distribution of identified births in 2012.

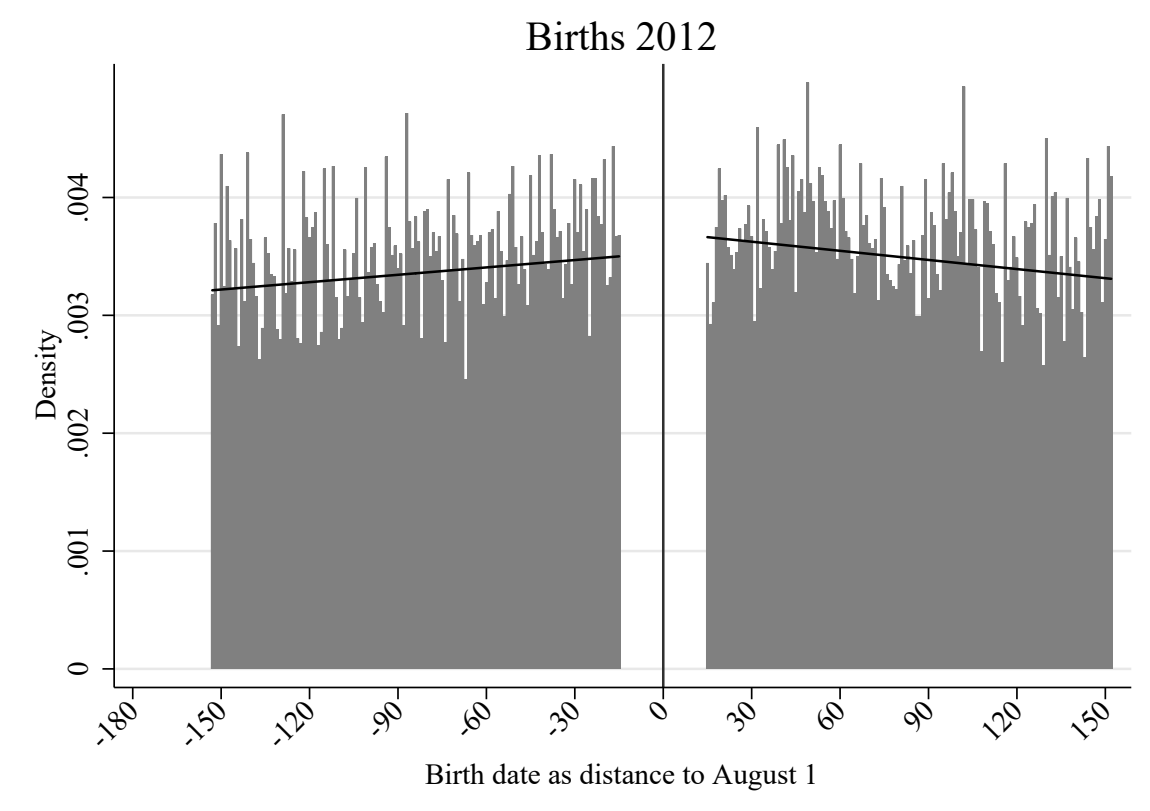

Source: Own calculations based on BeH data for for children born between March and December 2012, West Germany only.OIAB 
Figure A.2: Take-up rate of home care subsidy in Schleswig-Holstein.

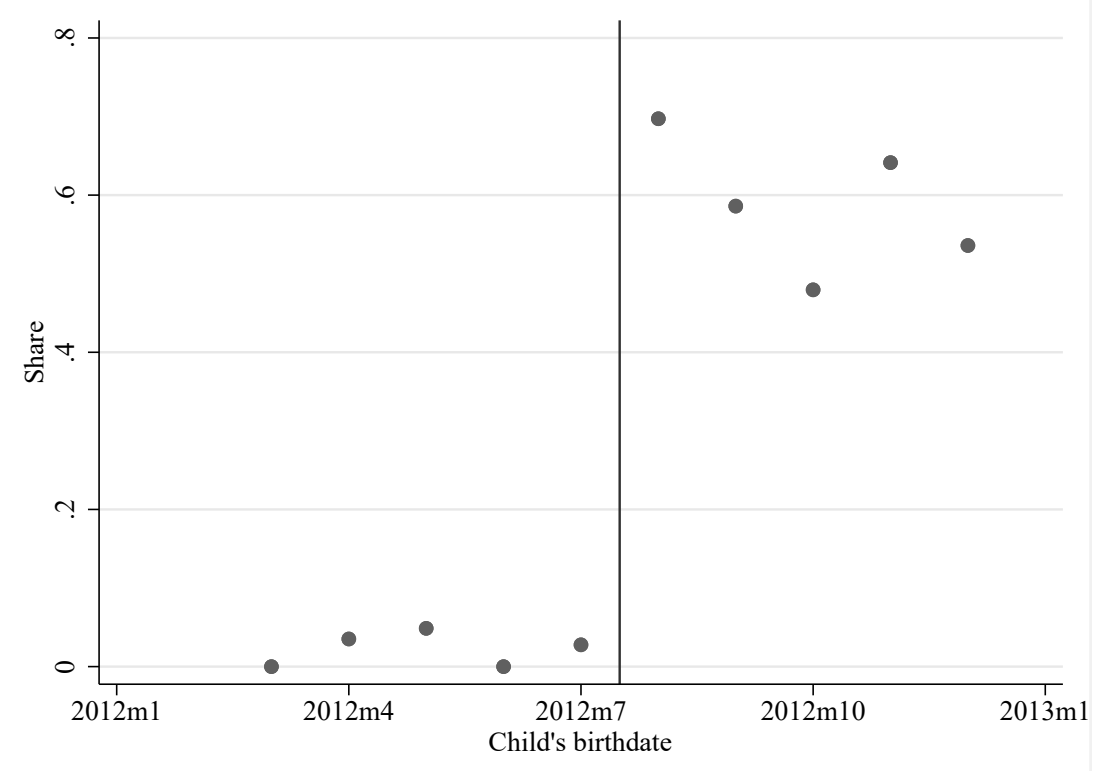

Source: Own calculations based on KiBS data for for children born between March and December 2012, Schleswig-Holstein only. OIAB 
Figure A.3: Kaplan-Meier graph for return-to-work patters.

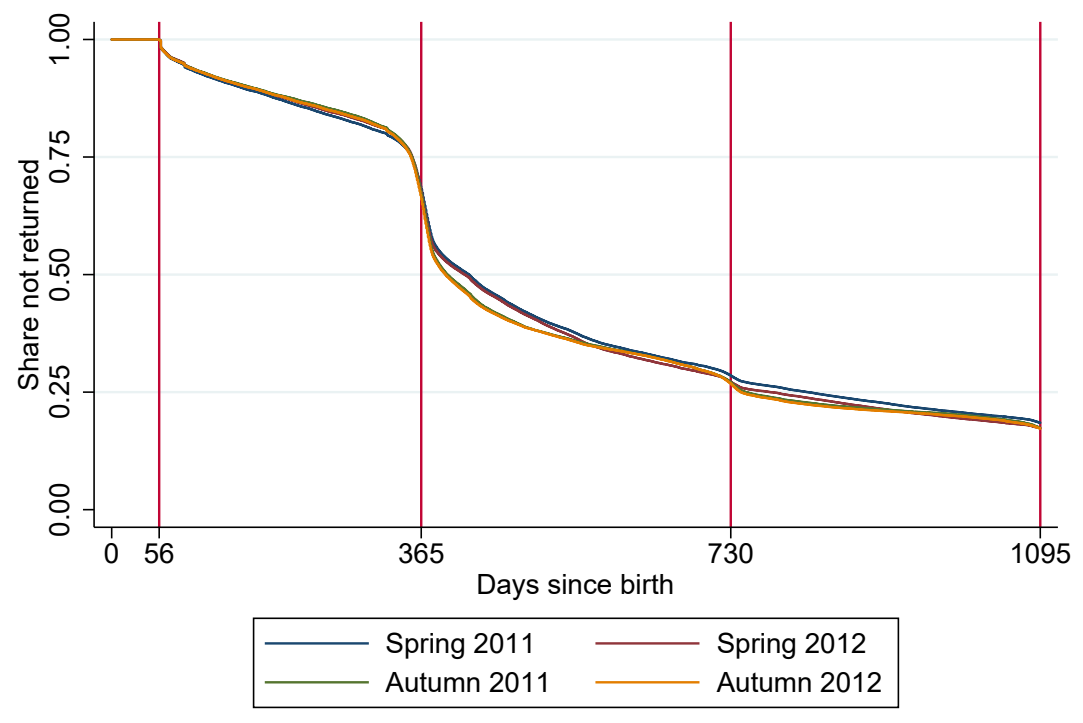

Source: Own calculations based on BeH data for for children born between March and December of 2011 and 2012, West Germany only. CIAB 
Table A.1: Literature review

\begin{tabular}{|c|c|c|c|c|c|}
\hline Study & Country & Subsidy and eligibility criteria & Target group & Data and methods & Main results \\
\hline $\mathrm{Naz}(2004)$ & Norway & $\begin{array}{l}\text { Unconditional (and tax-exempt) cash sub- } \\
\text { sidy (initially up to 3,000 NOK monthly) if } \\
\text { parents did not use any publicly subsidised } \\
\text { childcare, adjusted proportionally for par- } \\
\text { ents who used formal daycare only part-time }\end{array}$ & $\begin{array}{l}\text { Parents of one- and two- } \\
\text { year-old children }\end{array}$ & $\begin{array}{l}\text { Two pooled waves of } \\
\text { cross-sectional survey } \\
\text { data from } 1998 \text { and 1999, } \\
\text { DiD }\end{array}$ & $\begin{array}{l}\text { reduction of mother's working hours; } \\
\text { within-couple specialisation in mar- } \\
\text { ket work increased, especially for } \\
\text { high-educated mothers }\end{array}$ \\
\hline Schøne (2004) & Norway & same as Naz (2004) & same as Naz (2004) & $\begin{array}{l}\text { Administrative data, } 1997 \\
\text { to 2000, triple DiD }\end{array}$ & $\begin{array}{l}\text { negative effect on mothers' labour } \\
\text { force participation rate (-3 pp.); } \\
\text { modest reduction in annual working } \\
\text { hours conditional on participation } \\
\text { (-46 hours) }\end{array}$ \\
\hline Drange (2015) & Norway & same as Naz (2004) & same as Naz (2004) & $\begin{array}{l}\text { Administrative data, } \\
\text { 1994-2000, DiD }\end{array}$ & $\begin{array}{l}\text { small negative effect on mothers' } \\
\text { labour force participation rate }(-2.4 \\
\text { pp) }\end{array}$ \\
\hline $\begin{array}{l}\text { Thoresen/ } \\
\text { Vattø (2019) }\end{array}$ & Norway & $\begin{array}{l}\text { Cash-for-care reform from } 2012 \text { which in- } \\
\text { creased the home care allowance for chil- } \\
\text { dren aged } 13-18 \text { months from } 3303 \text { NOK ( } 401 \\
\text { EUR) to } 5000 \text { NOK ( } 620 \text { EUR) and abolished } \\
\text { the care allowance for 2-year old children } \\
\text { (3303 NOK) }\end{array}$ & $\begin{array}{l}\text { Parents of one- and two- } \\
\text { year old children }\end{array}$ & $\begin{array}{l}\text { Survey and administra- } \\
\text { tive data from 2008-2013, } \\
\text { structural model and DiD } \\
\text { approach }\end{array}$ & $\begin{array}{l}\text { No effect on the earnings of moth- } \\
\text { ers of } 1 \text {-year-olds, positive effects on } \\
\text { the labour earnings of mothers of } 2 \text { - } \\
\text { year-olds. Increasing childcare par- } \\
\text { ticipation rates for mothers of } 2 \text {-year- } \\
\text { olds, decreasing participation rates } \\
\text { for mothers of } 1 \text {-year-olds. Simula- } \\
\text { tion of the abolition of the home care } \\
\text { allowance for all age groups implies } \\
\text { very small effects on maternal work- } \\
\text { ing hours (+0.64 hours per week) and } \\
\text { small increases in childcare partici- } \\
\text { pation rates (+4pp, baseline } 85.1 \% \text { ) }\end{array}$ \\
\hline
\end{tabular}

Continued on next page 
Table A.1 - continued from previous page

\begin{tabular}{|c|c|c|c|c|c|}
\hline Study & Country & Subsidy & Target group & Data and methods & Main results \\
\hline $\begin{array}{l}\text { Giuliani/Du- } \\
\text { vander (2017) }\end{array}$ & Sweden & $\begin{array}{l}\text { (re)Introduction of a cash-for-care policy in } \\
\text { Sweden in } 2008 \text { of } 3000 \text { SEK ( } 325 \text { EUR) in } \\
\text { several municipalities; could be used part- } \\
\text { time; could not be combined with other so- } \\
\text { cial transfers. }\end{array}$ & $\begin{array}{l}\text { Parents of one- to three- } \\
\text { year-old children }\end{array}$ & $\begin{array}{l}\text { Aggregated data exploit- } \\
\text { ing between-municipality } \\
\text { variation from } 2007 \text { to } \\
2012\end{array}$ & $\begin{array}{l}\text { negative association between sub- } \\
\text { sidy and female employment rates in } \\
\text { rural and mixed areas; results should } \\
\text { be interpreted with care due to data } \\
\text { limitations (as pointed out by the au- } \\
\text { thors) }\end{array}$ \\
\hline $\begin{array}{l}\text { Kosonen } \\
\text { (2014) }\end{array}$ & Finland & $\begin{array}{l}\text { Universal subsidy, paid out irrespective of in- } \\
\text { come, could be used to finance private care } \\
\text { arrangements. Parents were not allowed to } \\
\text { use public childcare services part-time. Ben- } \\
\text { efit ranges from around } 300 \text { to } 700 \text { Euros per } \\
\text { months, depending on families' characteris- } \\
\text { tics; municipalities provide additional sup- } \\
\text { plements on top of the national allowance }\end{array}$ & $\begin{array}{l}\text { Parents of children aged } \\
\text { under } 9-36 \text { months }\end{array}$ & $\begin{array}{l}\text { Administrative income } \\
\text { data from } 1994 \text { to } 2005 \text {, } \\
\text { triple DiD approach } \\
\text { exploiting variation in } \\
\text { municipality top-up al- } \\
\text { lowances and eligibility } \\
\text { by children's age }\end{array}$ & $\begin{array}{l}\text { increasing the municipal sup- } \\
\text { plement by } 100 \text { Euros decreases } \\
\text { maternal labour market participa- } \\
\text { tion (- } 3.6 \text { percentage points / }-10 \%) \\
\text { annual earnings (-1,100 EUR) }\end{array}$ \\
\hline
\end{tabular}

Source: Own compilation. 
Table A.2: Key characteristics of the different datasets

\begin{tabular}{|l|l|l|l|}
\hline & Employment data & Childcare data & School entrance data \\
\hline Regions & Germany & Germany & Schleswig-Holstein \\
\hline Sampling & Universe & Two-way stratified sampling & Universe \\
\hline Birth cohorts & $2008-2013$ & 2011-2012 & $2007-2012$ \\
\hline Outcomes & $\begin{array}{l}\text { 1) Ever returned to work; 2) Cumulated days } \\
\text { in employment; 3) cumulated labour in- } \\
\text { come. All outcomes measured three years } \\
\text { after child birth. }\end{array}$ & $\begin{array}{l}\text { Whether children use subsidised provider as } \\
\text { childcare. }\end{array}$ & $\begin{array}{l}\text { Standardised (binary) measures from } \\
\text { SOPESS instrument, if children have difficul- } \\
\text { ties in the following domains: 1) cognition, } \\
\text { 2) coordination, 3) hand-eye coordination, } \\
\text { 4) counting, and 5) numeracy }\end{array}$ \\
\hline Migration background & 1) Mother's nationality. & $\begin{array}{l}\text { 1) Mother's country of origin, 2) main lan- } \\
\text { guage spoken at home }\end{array}$ & $\begin{array}{l}\text { 1) Mother's country of origin, 2) main lan- } \\
\text { guage spoken at home }\end{array}$ \\
\hline
\end{tabular}

Source: Own compilation 
Table A.3: Effect on social assistance receipt

\begin{tabular}{|c|c|c|c|}
\hline & (1) & (2) & (3) \\
\hline \multicolumn{4}{|c|}{ Ever on social assistance within 36 months } \\
\hline \multirow[t]{2}{*}{2012 X Autumn } & -0.000 & 0.000 & -0.001 \\
\hline & $(0.002)$ & $(0.002)$ & $(0.005)$ \\
\hline Mean 2012 Spring & 0.132 & 0.132 & 0.132 \\
\hline \multicolumn{4}{|l|}{ Specification } \\
\hline Did & $\checkmark$ & $\checkmark$ & $\checkmark$ \\
\hline$+X_{i}$ & & $\checkmark$ & $\checkmark$ \\
\hline + running var & & & $\checkmark$ \\
\hline
\end{tabular}

Notes: $\mathrm{N}=580324$. Controls in $X_{i}$ are district fixed effects, age at birth dummies $(<25,25-30,30-35,30-40,>40$, wage prior to birth dummies (<20, 20-40, 40-60, 60-80, 80-100, 100-120, >120), tertiary education (dummy), dummies for missing values in either. Robust standard errors in parentheses.

Significance levels: ${ }^{*} p<0.10,{ }^{* *} p<0.05,{ }^{* * *} p<0.01$.

Source: Own calculations based on BeH data for for children born between March 2008 and December 2013, West Germany only. CIAB 
Table A.4: DiD-balancing - employment data

\begin{tabular}{lcc}
\hline Variable & 2012 X Autumn & Standard error \\
\hline Age at birth & -0.046 & $(0.031)$ \\
Wage prior to birth & $0.533^{*}$ & $(0.288)$ \\
Full time & -0.003 & $(0.003)$ \\
No tertiary degree & 0.004 & $(0.003)$ \\
Tertiary degree & -0.003 & $(0.003)$ \\
German citizen & 0.000 & $(0.002)$ \\
Childcare Ratio 2012 $(\mathrm{N}=483328)$ & -0.000 & $(0.000)$ \\
\hline
\end{tabular}

Notes: Robust standard errors in parentheses.

Significance levels: ${ }^{\star} p<0.10,{ }^{\star *} p<0.05,{ }^{\star * \star} p<0.01$.

Source: Own calculations based on BeH data for for children born between March 2008 and December 2013, West Germany only.@IAB 
Table A.5: DiD-balancing - school entrance examinations data

\begin{tabular}{lcc}
\hline Variable & 2012 X Autumn & Standard error \\
\hline Age at testing & -0.121 & $(0.106)$ \\
Female & -0.024 & $(0.024)$ \\
Mother - highest education level & & \\
$\quad$ Missing & 0.027 & $(0.020)$ \\
$\quad$ Upper secondary & -0.034 & $(0.023)$ \\
$\quad$ Lower secondary & 0.000 & $(0.024)$ \\
Mother - country of origin & & \\
$\quad$ Missing & -0.011 & $(0.019)$ \\
$\quad$ Other country & 0.023 & $(0.018)$ \\
$\quad$ Germany & -0.013 & $(0.023)$ \\
Father - highest education level & & \\
$\quad$ Missing & -0.002 & $(0.022)$ \\
$\quad$ Upper secondary & -0.006 & $(0.022)$ \\
Lower secondary & 0.001 & $(0.024)$ \\
Father - highest education level & & \\
$\quad$ Missing & -0.020 & $(0.020)$ \\
Other country & -0.001 & $(0.017)$ \\
$\quad$ Germany & 0.021 & $(0.023)$ \\
Main language spoken at home & & \\
Missing & -0.006 & $(0.011)$ \\
German & -0.004 & $(0.020)$ \\
Foreign language & -0.010 & $(0.013)$ \\
Bilingual & 0.022 & $(0.014)$ \\
\hline
\end{tabular}

Notes: Sample based on districts that provide information on standardised SOPESS outcomes. Robust standard errors in parentheses.

Significance levels: ${ }^{\star} p<0.10,{ }^{\star \star} p<0.05,{ }^{\star \star \star} p<0.01$.

Source: Own calculations based on school entrance examinations data for children born in July or August between 2007 and 2012, Schleswig Holstein only. $\mathrm{N}=10,683$. CIAB 
Table A.6: Main Results for employment outcomes for Schleswig-Holstein

\begin{tabular}{|c|c|c|c|}
\hline & (1) & $(2)$ & (3) \\
\hline \multicolumn{4}{|c|}{ Ever worked within 36 months } \\
\hline \multirow[t]{2}{*}{2012 X Autumn } & -0.011 & -0.013 & 0.006 \\
\hline & $(0.012)$ & $(0.012)$ & $(0.027)$ \\
\hline Mean 2012 Spring & 0.870 & 0.870 & 0.870 \\
\hline \multicolumn{4}{|c|}{ Cumulated employment days within 36 months } \\
\hline \multirow[t]{2}{*}{2012 X Autumn } & -4.030 & -5.945 & -5.111 \\
\hline & $(10.357)$ & $(10.265)$ & $(23.298)$ \\
\hline Mean 2012 Spring & 489 & 489 & 489 \\
\hline \multicolumn{4}{|c|}{ Cumulated labour income within 36 months } \\
\hline \multirow[t]{2}{*}{2012 X Autumn } & 902.890 & 753.191 & -1230.441 \\
\hline & $(992.782)$ & $(871.304)$ & $(1950.684)$ \\
\hline Mean 2012 Spring & 30144 & 30144 & 30144 \\
\hline \multicolumn{4}{|l|}{ Specification } \\
\hline Did & $\checkmark$ & $\checkmark$ & $\checkmark$ \\
\hline$+X_{i}$ & & $\checkmark$ & $\checkmark$ \\
\hline + running var & & & $\checkmark$ \\
\hline
\end{tabular}

Notes: $\mathrm{N}=23442$. Controls in $X_{i}$ are district fixed effects, age at birth dummies $(<25,25-30,30-35,30-40,>40)$, wage prior to birth dummies (<20, 20-40, 40-60, 60-80, 80-100, 100-120, >120), tertiary education (dummy), dummies for missing values in either. Robust standard errors in parentheses.

Significance levels: ${ }^{*} p<0.10,{ }^{* *} p<0.05,{ }^{* * *} p<0.01$.

Source: Own calculations based on BeH data for for children born between March 2008 and December 2013, Schleswig-Holstein only. CIAB 
Table A.7: Robustness checks for children's outcomes

\begin{tabular}{|c|c|c|c|c|c|}
\hline & (1) & (2) & (3) & (4) & $(5)$ \\
\hline & Main & w/o controls & + Linear & + Quadratic & Placebo \\
\hline & & & time trends & time trends & 2011 \\
\hline \multicolumn{6}{|l|}{ Panel A: Main standardised outcomes } \\
\hline \multirow[t]{2}{*}{ Cognition difficulties } & -0.005 & 0.002 & 0.025 & 0.005 & -0.018 \\
\hline & $(0.018)$ & $(0.018)$ & $(0.024)$ & $(0.039)$ & $(0.019)$ \\
\hline \multirow[t]{2}{*}{ Hand-eye coordination difficulties } & -0.012 & -0.004 & -0.007 & -0.026 & 0.004 \\
\hline & $(0.019)$ & $(0.019)$ & $(0.025)$ & $(0.040)$ & $(0.020)$ \\
\hline \multirow[t]{2}{*}{ Attention difficulties } & -0.012 & -0.003 & -0.015 & -0.006 & -0.006 \\
\hline & $(0.018)$ & $(0.018)$ & $(0.024)$ & $(0.039)$ & $(0.018)$ \\
\hline \multirow[t]{2}{*}{ Counting difficulties } & -0.027 & -0.024 & -0.007 & 0.023 & $-0.037^{*}$ \\
\hline & $(0.019)$ & $(0.020)$ & $(0.026)$ & $(0.043)$ & $(0.021)$ \\
\hline \multirow[t]{2}{*}{ Quantitative difficulties } & 0.002 & 0.011 & 0.020 & 0.020 & -0.018 \\
\hline & $(0.017)$ & $(0.017)$ & $(0.023)$ & $(0.040)$ & $(0.019)$ \\
\hline \multicolumn{6}{|c|}{ Panel B: Additional non-standardised outcomes } \\
\hline \multirow[t]{2}{*}{ Medium support needs } & -0.023 & -0.023 & $-0.037^{\star}$ & $-0.065^{\star}$ & 0.024 \\
\hline & $(0.016)$ & $(0.017)$ & $(0.022)$ & $(0.037)$ & $(0.018)$ \\
\hline \multirow[t]{2}{*}{ High support needs } & -0.020 & -0.016 & -0.007 & -0.006 & -0.010 \\
\hline & $(0.014)$ & $(0.015)$ & $(0.019)$ & $(0.031)$ & $(0.015)$ \\
\hline \multirow[t]{2}{*}{ Speech difficulties } & 0.024 & 0.040 & 0.023 & -0.025 & 0.023 \\
\hline & $(0.024)$ & $(0.026)$ & $(0.033)$ & $(0.054)$ & $(0.026)$ \\
\hline \multirow[t]{2}{*}{ Motor skill difficulties } & -0.019 & -0.012 & -0.003 & 0.012 & -0.022 \\
\hline & $(0.020)$ & $(0.020)$ & $(0.027)$ & $(0.045)$ & $(0.021)$ \\
\hline $\mathrm{N}$ & 10012 & 10012 & 10012 & 10012 & 8431 \\
\hline
\end{tabular}

Notes: Robust standard errors in parentheses. Significance levels: ${ }^{\star} p<0.10,{ }^{\star \star} p<0.05,{ }^{\star \star \star} p<0.01$. Source: Own calculations based on school entrance examinations data for children born in July or August between 2007 and 2012, Schleswig Holstein only. CIAB 
Table A.8: Take-up of home care subsidy by parents' wage tercile prior to birth.

\begin{tabular}{lccc}
\hline & \multicolumn{3}{c}{ Mother's net wage } \\
Father's net wage & Low $(\leq 1291$ Euros $)$ & Medium & High $(\geq 2000$ Euros $)$ \\
\hline Low $(\leq 1890$ Euros $)$ & 0.682 & 0.648 & 0.449 \\
Observations & 283 & 289 & 165 \\
Medium & 0.754 & 0.691 & 0.506 \\
Observations & 280 & 275 & 294 \\
High ( $\geq 2800$ Euros $)$ & 0.655 & 0.661 & 0.459 \\
Observations & 200 & 225 & 435 \\
\hline
\end{tabular}

Source: Own calculations based on KiBS for children born between August 2012 and December 2013, WestGermany only, children aged 12-36 months, using cross-sectional survey weights. CIAB 


\section{Imprint}

\section{IAB-Discussion Paper 25|2020EN}

\section{Publication Date}

10 August 2020

\section{Publisher}

Institute for Employment Research

of the Federal Employment Agency

Regensburger Straße 104

90478 Nürnberg

Germany

\section{All rights reserved}

Reproduction and distribution in any form - also in parts - requires the permission of the FDZ

\section{Download}

http://doku.iab.de/discussionpapers/2020/dp2520.pdf

All publications in the series "IAB-Discusssion Paper" can be downloaded from

https://www.iab.de/en/publikationen/discussionpaper.aspx

Website

www.iab.de/en

\section{Corresponding author}

Michael Oberfichtner

Phone +49 (911) 1794473

E-Mail michael.oberfichtner@iab.de 